\title{
Kinetic Control of $\mathrm{Mg}^{2+-}$ dependent Melting of Duplex DNA Ends by E. coli RecBC
}

\author{
C. Jason Wong ${ }^{\#}$ and Timothy M. Lohman ${ }^{\star}$ \\ Department of Biochemistry and Molecular Biophysics Washington University School of Medicine \\ 660 S. Euclid Avenue, Box 8231 Saint Louis, MO 63110-1093, USA
}

\section{Abstract}

E. coli RecBCD is a highly processive DNA helicase involved in double strand break repair and recombination that possesses two helicase/translocase subunits with opposite translocation directionality ( $\operatorname{RecB}\left(3^{\prime}\right.$ to 5') and $\operatorname{RecD}\left(5^{\prime}\right.$ to $\left.3^{\prime}\right)$ ). RecBCD has previously been shown to melt out $\sim 5-6$ base pairs upon binding to a blunt-ended duplex DNA in a $\mathrm{Mg}^{2+}$-dependent, but ATPindependent reaction. Here we examine the binding of $E$. coli RecBC helicase (minus RecD), also a processive helicase, to duplex DNA ends in the presence and absence of $\mathrm{Mg}^{2+}$ in order to determine if RecBC can also melt a duplex DNA end in the absence of ATP. Equilibrium binding of RecBC to DNA substrates with ends possessing pre-formed 3' and/or 5'-single stranded (ss)-(dT) ${ }_{n}$ flanking regions (tails) ( $n$ varying from zero to 20 nucleotides) was examined by competition with a fluorescently labeled reference DNA and by isothermal titration calorimetry (ITC). The presence of $\mathrm{Mg}^{2+}$ enhances the affinity of RecBC for DNA ends possessing 3' or 5'-(dT) ${ }_{n}$ ss-DNA tails with $n$ $<6$ nucleotides, with the relative enhancement decreasing as $n$ increases from zero to six nucleotides. No effect of $\mathrm{Mg}^{2+}$ was observed for either the binding constant or the enthalpy of binding $\left(\Delta H_{\mathrm{obs}}\right)$ for RecBC binding to DNA with ss-DNA tail lengths, $n \geq 6$ nucleotides. Upon RecBC binding to a blunt duplex DNA end in the presence of $\mathrm{Mg}^{2+}$, at least four base pairs at the duplex end become accessible to $\mathrm{KMnO}_{4}$ attack, consistent with melting of the duplex end. Since $\mathrm{Mg}^{2+}$ has no effect on the affinity or binding enthalpy of RecBC for a DNA end that is fully pre-melted, this suggests that the role of $\mathrm{Mg}^{2+}$ is to overcome a kinetic barrier to melting of the DNA by RecBC and presumably also by RecBCD. These data also provide an accurate estimate $\left(\Delta H_{\mathrm{obs}}=8 \pm 1 \mathrm{kcal} / \mathrm{mol}\right)$ for the average enthalpy change associated with the melting of a DNA base pair by RecBC.

\section{Keywords}

fluorescence; motor protein; helicase; recombination; kinetics, thermodynamics

\section{Introduction}

Helicases are a class of motor enzymes that play critical roles in all aspects of DNA and RNA metabolism. These enzymes catalyze the separation of double-stranded (ds) DNA (or RNA) to form the single stranded (ss) DNA intermediates required for DNA replication,

\footnotetext{
*Address correspondence to: T.M. Lohman Department of Biochemistry and Molecular Biophysics Washington University School of Medicine 660 S. Euclid Ave. St. Louis, MO 63110 314-362-4393.

\#Current address: Section of Microbiology University of California, Davis One Shields Ave, Davis, CA 95616

Publisher's Disclaimer: This is a PDF file of an unedited manuscript that has been accepted for publication. As a service to our customers we are providing this early version of the manuscript. The manuscript will undergo copyediting, typesetting, and review of the resulting proof before it is published in its final citable form. Please note that during the production process errors may be discovered which could affect the content, and all legal disclaimers that apply to the journal pertain.
} 
recombination and repair via the coupling of energy from nucleoside triphosphate (NTP) binding and hydrolysis $1 ; 2 ; 3 ; 4$. To function processively, helicases must also translocate along the DNA filament. Such enzymes can also disrupt protein-DNA complexes $5 ; 6$ and this appears to provide an important biological function $7 ; 8$.

The E. coli RecBCD helicase is responsible for the majority of recombinational repair at dsDNA breaks 9; 10. RecBCD is a heterotrimeric enzyme consisting of the RecB (134 kDa), RecC (129 kDa) and RecD (67 kDa) subunits. Both the RecB and RecD subunits are superfamily 1 (SF1) DNA helicases 11 , but unwind dsDNA with opposite polarities; RecB is a 3' to 5' helicase/translocase ${ }^{12}$, while RecD is a 5' to 3' helicase/translocase $13 ; 14$. RecBCD binds and initiates DNA unwinding from a blunt or nearly blunt DNA end, the enzyme generates a 3'-ended ssDNA intermediate after encountering a recombination hotspot, called Chi $(\chi)$ (5'-GCTGGTGG-3') $15 ; 16 ; 17$. After Chi recognition, RecBCD then facilitates the loading of the RecA protein onto the unwound 3' -ssDNA ${ }^{18}$. The RecA-bound ssDNA filament then forms a joint molecule with a homologous region of DNA to initiate a recombination event. The RecBC enzyme, lacking the RecD subunit, can also function as a processive helicase and is capable of facilitating homologous recombination in vivo $19 ; 20$. However, the nuclease activity of RecBC is greatly attenuated $21 ; 22 ; 23 ; 24$ even though the nuclease site is located within the $30-\mathrm{kDa}$ C-terminal domain of the RecB subunit $25 ; 26 ; 27$, indicating that the nuclease activity is stimulated by the RecD subunit.

Both RecBCD and RecBC enzymes initiate DNA unwinding from duplex ends, including blunt ends $28 ; 29 ; 30 ; 31 ; 32 ; 33$. Studies of initiation complexes formed between RecBCD and a blunt-ended duplex DNA show that the RecB subunit can be crosslinked to the 3'-strand of the duplex end while the RecC and RecD subunits can be crosslinked to the 5' -strand ${ }^{34}$. Furthermore, five to six base pairs (bp) at the duplex end within the RecBCD-dsDNA initiation complex become accessible to $\mathrm{KMnO}_{4}$ attack in a $\mathrm{Mg}^{2+}$-dependent but ATP-independent manner ${ }^{35}$, suggesting that RecBCD melts out or unwinds $4-5$ bp upon binding to a blunt DNA end. A crystal structure of a RecBCD-DNA complex, formed in the presence of $\mathrm{Ca}^{2+}$, but without ATP, shows a melting of $\sim$ four bp at the duplex DNA end 27 .

Equilibrium binding of both RecBCD and RecBC to duplex DNA ends is enhanced if the DNA end possesses pre-formed 3' and/or 5' ssDNA flanking regions ${ }^{36}$, with RecBC showing optimal binding to a DNA end with both $3{ }^{\prime}-(\mathrm{dT})_{6}$ and $5^{\prime}-(\mathrm{dT})_{6}$ tails, whereas RecBCD binds optimally to a DNA end with a $3^{\prime}-(\mathrm{dT})_{6}$ tail, but a $5^{\prime}-(\mathrm{dT})_{10}$ tail ${ }^{37}$. These results suggest that both enzymes are capable of disrupting $\sim$ six bp upon binding to a blunt duplex DNA end ${ }^{37}$; however, melting of a duplex DNA end by RecBC has not been demonstrated. In the current study, we have compared the effects of $\mathrm{Mg}^{2+}$ on the equilibrium binding of RecBC to duplex DNA ends possessing variable lengths of pre-existing ssDNA tails as well as on the patterns of $\mathrm{KMnO}_{4}$ protection. These results demonstrate that RecBC is also able to melt out at least four bp upon binding to a duplex DNA end in a $\mathrm{Mg}^{2+}$-dependent, but ATP-independent reaction. Our studies also suggest that the effect of $\mathrm{Mg}^{2+}$ is to relieve a kinetic block to DNA melting by RecBC, rather than to affect the equilibrium binding affinity of RecBC for the DNA.

\section{Results \\ DNA substrate design}

The experiments described here were performed using the series of 60-bp Cy3-labeled reference DNA (I to III) and the unlabeled DNA molecules (IV to VI) shown schematically in Figure 1a. The 60-bp duplex length ensures that one molecule of RecBC can bind independently to each duplex end without interference from protein binding to the other end 37. The almost identical ends within each DNA duplex molecule simplify the data analysis as RecBC binds to both ends with the same affinity within experimental error ${ }^{37}$. The equilibrium 
constant for RecBC binding to an end of a Cy3-labeled reference DNA molecule (I to III) is referred to hereafter as $K_{\mathrm{BC}, \mathrm{R}}$, while $K_{\mathrm{BC}}$ denotes the equilibrium constant for RecBC binding to an unlabeled duplex DNA end (IV to VI). The sequences of DNA strands used to form the duplex DNA molecules in Figure 1a are given in Figure 1c.

\section{Effects of $\mathrm{Mg}^{2+}$ on RecBC binding to reference DNA I}

Generally, an increase in the bulk solution $[\mathrm{NaCl}]$ will decrease the equilibrium binding constant for most protein-DNA interactions due to the fact that the $\mathrm{Na}^{+}$counterion is displaced from the DNA when the protein binds $38 ; 39 ; 40 ; 41$. If there is a mixture of $\mathrm{Na}^{+}$and $\mathrm{Mg}^{2+}$ in the buffer and if $\mathrm{Mg}^{2+}$ interacts only with the DNA and not the protein, then the $\mathrm{Mg}^{2+}$ should compete with both the $\mathrm{Na}^{+}$and protein for binding to the DNA. Thus, if $\mathrm{Mg}^{2+}$ were only serving as a competitor for DNA binding, then the protein-DNA binding constant measured in the presence of $\mathrm{Mg}^{2+}$ should always be less than or equal to the binding constant measured in the absence of $\mathrm{Mg}^{2+}$ at the same $[\mathrm{NaCl}] 42 ; 43$.

We examined the effects of $\mathrm{Mg}^{2+}$ on the $[\mathrm{NaCl}]$-dependence of the equilibrium constant for RecBC binding to a duplex DNA end that we expect will be partially melted in the presence of $\mathrm{Mg}^{2+}$. For this purpose we examined RecBC binding to reference DNA I which has a Cy3 fluorophore on each 5'-end of the DNA and a 3'-(dT) $)_{4}$ tail. Based on our previous studies 37 , RecBC binding to each end of this DNA is expected to melt an additional $2 \mathrm{bp}$ in the presence of $\mathrm{Mg}^{2+}$. We first examined the dependence of the RecBC-DNA end binding constant, $K_{\mathrm{BC}, \mathrm{R}}$, on $[\mathrm{NaCl}]$ by performing "salt-back titrations" in the presence and absence of $10 \mathrm{mM}$ $\mathrm{MgCl}_{2}$ as described 44; 45 (see Materials and Methods) and the results are plotted in Figure 2. At the starting $[\mathrm{NaCl}]$ of $0.10 \mathrm{M}, \mathrm{RecBC}$ binds with higher affinity to the DNA end in the presence of $10 \mathrm{mM} \mathrm{MgCl}_{2}\left(K_{\mathrm{BC}, \mathrm{R}}=(4.8 \pm 0.3) \times 10^{7} \mathrm{M}^{-1}\right.$ in $10 \mathrm{mM} \mathrm{MgCl}_{2}$ vs. $(2.3 \pm 0.2) \times$ $10^{7} \mathrm{M}^{-1}$ in the absence of $\mathrm{MgCl}_{2}$ ). Upon increasing the $[\mathrm{NaCl}]$ we observe a decrease in $K_{\mathrm{BC}, \mathrm{R}}$ both in the presence and absence of $10 \mathrm{mM} \mathrm{MgCl}_{2}$. Plots of $\log K_{\mathrm{BC}, \mathrm{R}} \mathrm{vs} . \log [\mathrm{NaCl}]$ are linear within experimental error over the range from 0.1 to $0.85 \mathrm{M} \mathrm{NaCl}$, with log-log slopes of $-1.9 \pm 0.4$ in the presence of $10 \mathrm{mM} \mathrm{MgCl}$ and $-4.5 \pm 0.6$ in the absence of $\mathrm{MgCl}_{2}$. Therefore, at any [ $\mathrm{NaCl}], K_{\mathrm{BC}, \mathrm{R}}$ is always larger in the presence of $10 \mathrm{mM} \mathrm{MgCl} 2$ with the relative effect of $\mathrm{MgCl}_{2}$ increasing with increasing [NaCl] (Figure 2). This result is opposite to the expected result if $\mathrm{Mg}^{2+}$ were to bind only to the DNA and compete for binding of $\mathrm{Na}^{+}$ and RecBC since under those circumstances the values of $K_{\mathrm{BC}, \mathrm{R}}$ should converge, rather than diverge at high $[\mathrm{NaCl}]{ }^{42 ; 43}$. This result provides a clear indication that $\mathrm{Mg}^{2+}$ also binds directly to the RecBC protein and/or the RecBC-DNA complex, and facilitates RecBC binding to the DNA end. The simplest interpretation of the slopes of the plots in Figure 2 indicates that approximately five ions $\left(\mathrm{Na}^{+}\right.$and/or $\mathrm{Cl}^{-}$) are released upon RecBC binding to an end of reference DNA I in the absence of $\mathrm{MgCl}_{2}$, while $\sim$ two ions $\left(\mathrm{Na}^{+}\right.$and/or $\left.\mathrm{Cl}^{-}\right)$are released when RecBC binds to a DNA $\mathbf{I}$ end in the presence of $10 \mathrm{mM} \mathrm{MgCl}_{2}$.

Independent experiments indicated that the fluorescence intensity of the Cy3 labeled DNA is unaffected by increases in $[\mathrm{NaCl}]$, thus enabling us to use "salt back" titrations to obtain estimates of $K_{\mathrm{BC}, \mathrm{R}}$. As a further check, we also measured $K_{\mathrm{BC}, \mathrm{R}}$ directly at 300 and $400 \mathrm{mM}$ $\mathrm{NaCl}$ by determining a full binding isotherm (titrating RecBC into DNA I and monitoring the $\mathrm{Cy} 3$ fluorescence increase). The values of $K_{\mathrm{BC}, \mathrm{R}}$ determined directly (triangles in Figure 2) and by the salt back titration (circles in Figure 2) agree within experimental uncertainty.

\section{The pre-existing ss-(dT) $n$ tail length influence the effects of $\mathrm{Mg}^{2+}$ on $\mathrm{RecBC}$ binding to DNA ends}

The data in Figure 2 show that $K_{\mathrm{BC}, \mathrm{R}}$ for RecBC binding to a DNA end with a 3'-(dT) ${ }_{4}$ ssDNA tail is increased in the presence of $10 \mathrm{mM} \mathrm{MgCl}_{2}$. As mentioned above, we anticipate that two bp within the duplex region at the ss-ds-DNA junction should be melted upon RecBC binding 
to such a DNA end. We next determined the relative equilibrium constants for RecBC binding to DNA ends possessing different lengths of pre-existing ss-(dT) ${ }_{n}$ tails. For these studies we measured equilibrium constants, $K_{\mathrm{BC}}$, for RecBC binding to the non-fluorescent DNA series IV (variable 3'-(dT) $)_{n}$ tail) and $\mathbf{V}$ (variable 5' $-(\mathrm{dT})_{n}$ tail) in the presence and absence of $10 \mathrm{mM}$ $\mathrm{MgCl}_{2}$ using competition titration experiments. These experiments were performed by titrating a mixture of reference DNA $\mathbf{I}$ and one of the competitor DNA IV or $\mathbf{V}$ series molecules with RecBC as described ${ }^{37}$. For each competitor DNA molecule, three experiments were performed in which the concentration of reference DNA I was maintained constant (20 nM) while the concentration of the non-fluorescent competitor DNA molecule was increased in each successive experiment. Data from all three experiments were analyzed globally to obtain $K_{\mathrm{BC}}$ using non-linear least square (NLLS) methods as described ${ }^{37}$ and the values of $K_{\mathrm{BC}}$ are presented in Table 1. The competition binding isotherms obtained from a representative experiment performed using a DNA IV series molecule with $n=8$ nucleotides are shown in Figure 3a. The relative fluorescence enhancement ( $\Delta F_{\text {obs }}$, defined in equation (2) in Materials and Methods) is plotted as a function of total [RecBC] together with simulated isotherms based on the best fit values of $K_{\mathrm{BC}}$ (Table 1) as described 37 .

Figure $3 \mathrm{~b}$ shows plots of the ratio of $K_{\mathrm{BC}}$ measured in the absence of $\mathrm{MgCl}_{2}$ to $K_{\mathrm{BC}}$ measured in the presence of $10 \mathrm{mM} \mathrm{MgCl} 2$ as a function of the length of the preexisting ss-(dT) $)_{n}$ tail. The dependences of $K_{\mathrm{BC}}$ on the length of the pre-existing ss- $(\mathrm{dT})_{n}$ tail are qualitatively similar in the presence or absence of $10 \mathrm{mM} \mathrm{MgCl} 2$ (Table 1). In both cases, a maximum in $K_{\mathrm{BC}}$ is observed for a DNA end with a pre-existing 3'- or a 5'-(dT) $)_{n}$ tail with $n \geq 6$ nucleotides. Importantly, the values of $K_{\mathrm{BC}}$ for the DNA IV and $\mathbf{V}$ series measured in the absence of $\mathrm{MgCl}_{2}$ are lower than $K_{\mathrm{BC}}$ measured in $10 \mathrm{mM} \mathrm{MgCl}_{2}$ when $n<6$ nucleotides (Table 1); however, for $n \geq 6$ nucleotides, $K_{\mathrm{BC}}$ is the same in the absence or presence of $10 \mathrm{mM}$ $\mathrm{MgCl}_{2}$. As shown in Figure $3 \mathrm{~b}$, the difference between $K_{\mathrm{BC}}$ measured in the absence and presence of $\mathrm{MgCl}_{2}$ decreases as the length of the preexisting ss-(dT) ${ }_{n}$ tail increases from zero to six nucleotides, with the values of $K_{\mathrm{BC}}$ becoming independent of the presence of $\mathrm{Mg}^{2+}$ for $n \geq 6$ nucleotides. The largest difference is observed for a blunt DNA end such that $K_{\mathrm{BC}}$ is $\sim 3$ times higher in the presence of $10 \mathrm{mM} \mathrm{MgCl}_{2}$. We also observed no effect of $10 \mathrm{mM}$ $\mathrm{MgCl}_{2}$ on the values of $K_{\mathrm{BC}}$ for a DNA VI molecule possessing pre-existing twin ss-(dT) 6 tails on both ends (open triangle in Figure $3 b$ ). Hence, $\mathrm{Mg}^{2+}$ only affects $K_{\mathrm{BC}}$ for RecBC binding to a DNA end with a 3'- or 5' $-(\mathrm{dT})_{n}$ tail if $n<6$ nucleotides. This suggests that the effect of $\mathrm{Mg}^{2+}$ is observed only when RecBC can potentially melt out some base pairs within a duplex DNA end.

\section{Effects of $\mathrm{Mg}^{2+}$ on melting of a DNA end by RecBC as examined by chemical protection of DNA}

Although the above binding studies suggest that RecBC melts some of the bp within the duplex DNA end region in the presence of $\mathrm{Mg}^{2+}$, we performed additional independent experiments to test this hypothesis. We performed $\mathrm{KMnO}_{4}$ footprinting experiments on the RecBC-bluntended-DNA complex to examine if base pairs are melted out in a $\mathrm{Mg}^{2+}$-dependent manner. $\mathrm{KMnO}_{4}$ preferentially oxidizes the $\mathrm{C} 5$-C6 double bond within unstacked thymine bases within DNA 46 and thus should detect melting of a duplex region containing thymidine base pairs. In fact, this approach was used by Farah and Smith 35 to demonstrate that RecBCD melts out four to five bp upon binding to a blunt duplex end. We used a blunt-ended DNA (the same DNA used in the fluorescence titration experiments discussed above) radiolabeled with ${ }^{32} \mathrm{P}$ at the 5'-end of the top strand (Figure 4). In addition to performing the experiments in buffer $\mathrm{M}$ in the presence or absence of $10 \mathrm{mM} \mathrm{MgCl} 2$, we also performed experiments in both 30 and $100 \mathrm{mM} \mathrm{NaCl}$ to determine if this range of monovalent salt concentration influences bp melting. As shown in Figure 4, the thymine base at position four (T4) is significantly more susceptible to $\mathrm{KMnO}_{4}$ attack in the presence of $10 \mathrm{mM} \mathrm{MgCl}_{2}$ and $\mathrm{RecBC}$, regardless of the 
$[\mathrm{NaCl}]$. This is the only thymine base within the six base pair region from the end of the 5 , $-32 \mathrm{P}$-labeled strand. None of the other thymines at other positions (T8 and beyond in Figure 4) exhibit any enhancement in susceptibility to $\mathrm{KMnO}_{4}$ attack in the presence of RecBC and $10 \mathrm{mM} \mathrm{MgCl}_{2}$. This indicates that at least four base pairs at the end of a blunt-ended DNA are melted upon binding of $\mathrm{RecBC}$ in a $\mathrm{Mg}^{2+}$-dependent manner.

\section{Dependence of DNA melting by $\mathrm{RecBC}$ on $\mathrm{Mg}^{2+}$ concentration}

The effects of $\mathrm{Mg}^{2+}$ on the equilibrium constant for RecBC binding to a DNA end, $K_{\mathrm{BC}, \mathrm{R}}$ and $K_{\mathrm{BC}}$, indicate that the binding of $\mathrm{Mg}^{2+}$ to RecBC increases its affinity for DNA ends containing pre-existing ss- $(\mathrm{dT})_{n}$ tails only if the tails are shorter than six nucleotides. The $\mathrm{KMnO}_{4}$ chemical protection experiments indicate that base pair melting by RecBC is also dependent on the presence of $\mathrm{Mg}^{2+}$. Together, these results indicate that the binding of $\mathrm{Mg}^{2+}$ to $\mathrm{RecBC}$ and/or the RecBC-DNA complex is linked to base pair melting by RecBC as has been demonstrated previously to be the case for RecBCD 35 . To further study these two processes and to estimate the equilibrium constant for $\mathrm{Mg}^{2+}$ binding to the RecBC-DNA complex, we examined the fluorescence intensity of Cy3 labeled reference DNA molecules (DNA I through III) when pre-bound with RecBC as a function of $\left[\mathrm{MgCl}_{2}\right]$. As shown in Figure 1a, DNA I has a Cy3 label on the 5' -end of the duplex and each end has a 3'-(dT) $)_{4}$ tail, DNA II has twin 3' and 5'$(\mathrm{dT})_{2}$ tails and a Cy3 label at the end of the 5' $-(\mathrm{dT})_{2}$ tail and DNA III has twin 3' and 5'$(\mathrm{dT})_{6}$ tails and a Cy3 label at the end of the $5^{\prime}-(\mathrm{dT})_{6}$ tail. Therefore, we expect that RecBC will melt out 2 bp from each end of DNA I and 4 bp from each end of DNA II in a $\mathrm{Mg}^{2+}$-dependent reaction. Experiments were performed by first saturating each reference DNA with RecBC in the absence of $\mathrm{MgCl}_{2}$ (buffer $\mathrm{M}$ plus $100 \mathrm{mM} \mathrm{NaCl}$ at $25^{\circ} \mathrm{C}$ ) and then titrating with $\mathrm{MgCl}_{2}$ while monitoring the $\mathrm{Cy} 3$ fluorescence signal.

The results of these experiments are presented in Figure 5a where the corrected Cy3 fluorescence ( $F_{i \text {,corr }}$ as defined in equation (1) in Material and Methods) is plotted as a function of the total $\left[\mathrm{MgCl}_{2}\right]$. The fluorescence intensities of $\mathrm{Cy} 3$ within the RecBCDNA I and RecBCDNA II complexes were enhanced upon titrating with $\mathrm{MgCl}_{2}$. In contrast, the $\mathrm{Cy} 3$ fluorescence signal of the RecBC-bound reference DNA III, which has twin ss- $(\mathrm{dT})_{6}$ tails on both ends, does not change upon addition of $\mathrm{MgCl}_{2}$. The largest enhancement in $\mathrm{Cy} 3$ fluorescence $(\sim 58 \%)$ is observed for the RecBC-bound DNA I, which has a 3'-(dT) $)_{4}$ tail, while the RecBCbound DNA II, which has twin ss- $(\mathrm{dT})_{2}$ tails, exhibits a smaller Cy3 fluorescence enhancement $(\sim 21 \%)$. Since the Cy3 fluorescence of reference DNA alone is independent of $\left[\mathrm{MgCl}_{2}\right]$ (data not shown), the observed enhancement of the $\mathrm{Cy} 3$ fluorescence signals of the RecBC-DNA I and RecBC-DNA II complexes upon titration with $\mathrm{MgCl}_{2}$ is due to the effects of $\mathrm{Mg}^{2+}$ on the RecBC-reference DNA complexes. The final fluorescence levels for all RecBC-reference DNA complexes are the same within experimental error, indicating that the final environments of the Cy3 fluorophores in all RecBC-DNA complexes are the same. The fact that only the reference DNA with ss-(dT) $)_{n}$ tails shorter than six nucleotides (DNA I and DNA II) exhibit fluorescence enhancement suggests that the increase in Cy3 fluorescence is due to DNA melting. No enhancement of the Cy3 signal was observed for reference DNA III which has twin ss- $(\mathrm{dT})_{6}$ tails, consistent with the expectation that no additional base pair melting should occur upon RecBC binding.

We also performed a $\mathrm{MgCl}_{2}$ titration of DNA I and DNA II in the presence of $400 \mathrm{mM} \mathrm{NaCl}$, since this higher $[\mathrm{NaCl}]$ should further reduce $\mathrm{Mg}^{2+}$ binding to the DNA. As shown in Figure $5 \mathrm{a}$, the results obtained in $400 \mathrm{mM} \mathrm{NaCl}$ are identical to the those obtained in $100 \mathrm{mM} \mathrm{NaCl}$, thus the binding of $\mathrm{Mg}^{2+}$ to the DNA appears to be weak enough at these high [NaCl] that it does not compete with the binding of $\mathrm{Mg}^{2+}$ to the RecBC-DNA complex. To examine this further, we calculated the expected extent of $\mathrm{Mg}^{2+}$ binding to a DNA duplex under these salt concentrations using the values of the $\mathrm{Mg}^{2+}$ binding constant determined as a function of 
$[\mathrm{NaCl}]$ from the study of non-specific interactions between lac repressor and calf thymus $\mathrm{DNA}^{42}$ as well as pentalysine and T7 DNA ${ }^{43}$. Based on these results one can calculate the probability $\left(P_{\mathrm{Na}}\right)$ that a nucleotide within the duplex DNA has only $\mathrm{Na}^{+}$and no $\mathrm{Mg}^{2+}$ associated with it when the duplex DNA is placed in a buffer containing both $\mathrm{Na}^{+}$and $\mathrm{Mg}^{2+}$ (see Appendix). These calculations indicate that at $100 \mathrm{mM} \mathrm{NaCl}, P_{\mathrm{Na}} \approx 0.62$ at the end of the titration when $10 \mathrm{mM} \mathrm{MgCl}_{2}$ is present. At $400 \mathrm{mM} \mathrm{NaCl}, P_{\mathrm{Na}} \approx 0.95$ at the end of the titration when $10 \mathrm{mM} \mathrm{MgCl} 2$ is present. We also note that the equilibrium constants for $\mathrm{Mg}^{2+}$ binding to duplex DNA used in the above calculations were determined for $\mathrm{Mg}^{2+}$ binding to long duplex DNA. Since the DNA used in our experiments is only $60 \mathrm{bp}$ long, there will be less $\mathrm{Mg}^{2+}$ binding to the shorter DNA than estimated from the calculations. Therefore we conclude that there should be relatively little $\mathrm{Mg}^{2+}$ bound to the DNA even at $10 \mathrm{mM} \mathrm{Mg}{ }^{2+}$, especially at $400 \mathrm{mM} \mathrm{NaCl}$. Although these results suggest that the binding of $\mathrm{Mg}^{2+}$ to the RecBC-DNA complex is relatively insensitive to the $[\mathrm{NaCl}]$, this may be complicated by any compensating effects due to the $[\mathrm{NaCl}]$-dependence of $\mathrm{Mg}^{2+}$ binding to the DNA.

As shown in Figure 5a, the midpoint of the $\mathrm{Mg}^{2+}$ titrations for DNA I performed in either 100 or $400 \mathrm{mM} \mathrm{NaCl}$ is $\sim 1.6( \pm 0.4) \mathrm{mM} \mathrm{MgCl} 2$ while titrations for DNA II exhibit a midpoint of $1.8( \pm 0.4) \mathrm{mM} \mathrm{MgCl}$. This indicates that the melting of base pairs in both DNA I and II has the same dependence on $\mathrm{MgCl}_{2}$ concentration despite the expectation that a different number of base pairs are melted in DNA I vs. II ( 2 vs. 4 bp, respectively).

To obtain estimates of the apparent equilibrium constant for $\mathrm{Mg}^{2+}$ binding to the RecBC and RecBC-DNA complex we analyzed the $\mathrm{MgCl}_{2}$ titrations quantitatively using a simple model that assumes only one $\mathrm{Mg}^{2+}$ binding site per RecBC (see Scheme 1 and Materials and Methods). This model ignores any binding of $\mathrm{Mg}^{2+}$ to duplex DNA; however, as discussed above, this is expected to be small at the high $[\mathrm{NaCl}](100 \mathrm{mM}$ and $400 \mathrm{mM})$ used in our experiments. NLLS analysis of the data using equation (17) (see Materials and Methods) yields a value of $K_{\mathrm{Mg}}^{\mathrm{BD}}=(5 \pm 2) \times 10^{2} \quad \mathrm{M}^{-1}$ for the equilibrium constant for $\mathrm{Mg}^{2+}$ binding to either a RecBCDNA I or a RecBC-DNA II complex, and a value of $K_{\mathrm{Mg}}^{\mathrm{B}}=(8 \pm 3) \quad \mathrm{M}^{-1}$ for the equilibrium constant for $\mathrm{Mg}^{2+}$ binding to RecBC, assuming only one $\mathrm{Mg}^{2+}$ binding site per RecBC.

Somewhat surprisingly, $\mathrm{Ca}^{2+}$ has identical effects on the $\mathrm{Cy} 3$ fluorescence signals of RecBCDNA complexes as $\mathrm{Mg}^{2+}$. As shown in Figure 5b, the traces obtained from titrations of the RecBC-DNA I complex with $\mathrm{CaCl}_{2}$ and $\mathrm{MgCl}_{2}$ are identical within experimental uncertainty. Titration of the RecBC-DNA III complex with $\mathrm{CaCl}_{2}$ also exhibits no change in $\mathrm{Cy} 3$ fluorescence intensity (Figure 5b). We also observed that RecBC binds to reference DNA I with the same affinity $\left(K_{\mathrm{BC}, \mathrm{R}}=(4.8 \pm 0.5) \times 10^{7} \mathrm{M}^{-1}\right)$ in either $10 \mathrm{mM} \mathrm{MgCl}_{2}$ or $10 \mathrm{mM}$ $\mathrm{CaCl}_{2}$ (data not shown). These data indicate that the observed equilibrium constant for the RecBC-DNA complex binding to one $\mathrm{Ca}^{2+}$ ion is identical to that for $\mathrm{Mg}^{2+}$. Even though a crystal structure of RecBCD bound to a duplex DNA in the presence of $\mathrm{Ca}^{2+}$ shows that RecBCD can melt out four bp at the end of the duplex 27 , our quantitative studies are somewhat surprising since $\mathrm{Mg}^{2+}$ and $\mathrm{Ca}^{2+}$ binding sites on proteins are expected to be different $47 ; 48$.

Since a $\mathrm{Ca}^{2+}$ ion is observed bound at the RecB nuclease domain active site in the crystal structure of RecBC-DNA complex ${ }^{27}$, we next tested if this site is responsible for the observed binding of $\mathrm{Mg}^{2+}$ by examining $\operatorname{RecB}^{\Delta \text { nuc }} \mathrm{C}$, which was reconstituted from $\mathrm{RecC}$ and a $\operatorname{RecB}$ nuclease domain deletion mutant $\left(\mathrm{RecB}^{\Delta \mathrm{nuc}}\right){ }^{26}$. Figure $5 \mathrm{c}$ shows that the $\left[\mathrm{MgCl}_{2}\right]$-dependence of the normalized enhancement of the Cy3 fluorescence signal of a RecB ${ }^{\Delta \text { nuc } C-D N A ~ I ~ c o m p l e x ~}$ is the same as observed for the normalized Cy3 fluorescence signal for a RecBC-DNA I complex. Therefore the nuclease domain of RecB is not responsible for the observed effect of $\mathrm{Mg}^{2+}$ on DNA melting. 


\section{Effects of $\mathrm{Mg}^{2+}$ on the observed enthalpy and heat capacity changes for RecBC binding to DNA ends}

As shown above, for RecBC binding to a DNA end possessing a pre-existing twin-ss-(dT) 6 tail (DNA VI), there is no effect of $\mathrm{Mg}^{2+}$ on $K_{\mathrm{BC}}$ and thus on the standard state binding free energy change, $\Delta G^{\circ}{ }_{\mathrm{obs}}=-R T \ln K_{\mathrm{BC}}$, (Figure $3 \mathrm{~b}$ and Table 1 ). While this suggests that there is no effect of $\mathrm{Mg}^{2+}$ on the energetics of the RecBC-DNA VI $(n=6)$ interaction, it is possible that there is an enthalpy/entropy compensation under the conditions used resulting in similar values of $K_{\mathrm{BC}}$. We therefore performed isothermal titration calorimetry (ITC) experiments to measure $\Delta H_{\mathrm{obs}}$ for RecBC binding to the ends of a DNA VI molecule with $n=6$ in the presence and absence of $10 \mathrm{mM} \mathrm{MgCl} 2$ over a temperature range from 5 to $25^{\circ} \mathrm{C}$. We also compared the $\Delta H_{\text {obs }}$ for RecBC binding to a DNA VI molecule with $n=6$, for which no bp melting is expected, to that for RecBC binding to a blunt-ended DNA molecule (DNA VI with $n=0$ ) for which bp melting is only expected to occur in the presence of $\mathrm{Mg}^{2+}$.

The results of two representative ITC experiments are shown in Figure 6a and $b$ where the heat of each injection normalized to the amount of DNA injected $\left(\Delta Q_{i, \text { norm }}\right.$ as defined in equation (20) in Materials and Methods) is plotted as a function of the ratio of total [DNA]/total [RecBC] (Buffer M, $100 \mathrm{mM} \mathrm{NaCl}$ ). The data were analyzed (see equations (18) to (20) in Materials and Methods) and the values of the observed enthalpy change ( $\left.\Delta H_{\mathrm{obs}}\right)$ for RecBC binding to one DNA end are presented in Table 2 and Figure $6 \mathrm{c}$. In the temperature range between 5 to $25^{\circ} \mathrm{C}, \Delta H_{\text {obs }}$ for RecBC binding to a DNA end containing twin-ss-(dT) 6 tails (DNA VI with $n=6$ ) is the same within experimental error, in the absence or presence of $10 \mathrm{mM} \mathrm{MgCl}_{2}$. This indicates that the complete thermodynamic profile $\left(\Delta G_{\mathrm{obs}}^{\circ}, \Delta H_{\mathrm{obs}}, \Delta S^{\circ}{ }_{\mathrm{obs}}\right.$, and $\left.\Delta C_{\mathrm{p}, \mathrm{obs}}\right)$ for RecBC binding to the pre-melted ends of DNA VI (with $n=6$ ) is identical in the absence or presence of $\mathrm{MgCl}_{2}$. Hence, $\mathrm{Mg}^{2+}$ has no effect on the energetics of RecBC binding to a fully pre-melted DNA end over the temperature range from 5 to $25^{\circ} \mathrm{C}$. RecBC binding to the DNA with twin-ss-(dT) 6 tails (DNA VI with $n=6$ ) exhibits the same $\Delta C_{\mathrm{p}, \text { obs }}$ in the presence or absence of $10 \mathrm{mM} \mathrm{MgCl}_{2}\left((-1.6 \pm 0.3)\right.$ and $(-1.6 \pm 0.4) \mathrm{kcal} \mathrm{mol}^{-1} \mathrm{~K}^{-1}$, respectively).

On the other hand, we observe a definite effect of $\mathrm{Mg}^{2+}$ on the values of $\Delta H_{\mathrm{obs}}$ and its heat capacity change $\left(\Delta C_{\mathrm{p}, \mathrm{obs}}=\left(\mathrm{d} \Delta H_{\mathrm{obs}} / \mathrm{d} T\right)_{P}\right)$ for RecBC binding to a blunt DNA end (DNA VI with $n=0$ ) (Table 2 and Figure 6c) measured over the temperature range from 15 to $25^{\circ} \mathrm{C}$. Interestingly, $\Delta C_{\mathrm{p}, \mathrm{obs}}$ for RecBC binding to a blunt-ended DNA in the presence of $10 \mathrm{mM}$ $\mathrm{MgCl}_{2}$ is very similar $\left((-1.2 \pm 0.2) \mathrm{kcal} \mathrm{mol}^{-1} \mathrm{~K}^{-1}\right)$, to $\Delta C_{\mathrm{p}, \mathrm{obs}}$ for $\mathrm{RecBC}$ binding to the twinss-(dT) 6 tailed DNA, although the values of $\Delta H_{\text {obs }}$ are much smaller in magnitude for RecBC binding to the blunt DNA end. In contrast, $\Delta C_{\mathrm{p}, \text { obs }}$ for RecBC binding to a blunt-ended DNA in the absence of $\mathrm{MgCl}_{2}\left((-0.5 \pm 0.3) \mathrm{kcal} \mathrm{mol}^{-1} \mathrm{~K}^{-1}\right)$ is about 2.5 times smaller in magnitude. Hence, a larger negative value of $\Delta C_{\mathrm{p}, \mathrm{obs}}$ is observed under conditions where the final state of the DNA has 6 unpaired bases when bound to RecBC.

We also used the competition fluorescence titration experiments to examine the effects of 10 $\mathrm{mM} \mathrm{MgCl} 2$ on $K_{\mathrm{BC}}$ for RecBC binding to a blunt DNA end (DNA VI with $n=0$ ) at 5,15 and $25^{\circ} \mathrm{C}$ and compared these values with the predicted temperature dependence of $K_{\mathrm{BC}}$ based on the $\Delta C_{\mathrm{p}, \mathrm{obs}}$ and $\Delta H_{\mathrm{obs}}$ values obtained from the ITC studies (Table 2). The results are presented in Table 3 and plotted in Figure 6d. The lines in Figure 6d are simulations using equation (22) and the $\Delta H_{\mathrm{obs}}$ and $\Delta C_{\mathrm{p}, \text { obs }}$ values from Table 2. As shown in Figure 6d, there is excellent agreement between the measured values of $\ln K_{\mathrm{BC}}$ both in the presence and absence of $\mathrm{MgCl}_{2}$ and those calculated using the parameters obtained from the ITC studies.

\section{Enthalpic cost of base pair melting}

We next performed a series of experiments to obtain an estimate of the $\Delta H_{\text {obs }}$ for melting a base pair within the RecBC-DNA end complex. For this purpose, we measured $\Delta H_{\mathrm{obs}}$ for 
RecBC binding to the ends of the series of DNA VI molecules containing twin ss- $(\mathrm{dT})_{n}$ tails, with $n=0,2,4,6,8,10$ and 20, in the presence of $10 \mathrm{mM} \mathrm{MgCl}_{2}$. We reasoned that, in the presence of $\mathrm{MgCl}_{2}$, six base pairs should be melted upon RecBC binding to a blunt DNA end (DNA VI with $n=0$ ), while no base pairs should be melted upon RecBC binding to a DNA end with twin ss-(dT) $)_{n}$ tails, where $n \geq 6$. Thus the difference between $\Delta H_{\text {obs }}$ for RecBC binding to a blunt DNA end and $\Delta H_{\mathrm{obs}}$ for RecBC binding to a DNA end with twin ss-(dT) ${ }_{6}$ tails should provide a measure of the enthalpic cost for melting six base pairs. Of course, this assumes that the energetic state of the final RecBC-DNA complex (with 6 bp melted) is unaffected by DNA base composition.

The results of these experiments are presented in Table 4 and Figure 7. $\Delta H_{\mathrm{obs}}$ for RecBC binding to one end of DNA VI is always negative and decreases linearly from $(-17 \pm 4) \mathrm{kcal}$ $\mathrm{mol}^{-1}$ to $(-64 \pm 3) \mathrm{kcal} \mathrm{mol}^{-1}$ as the lengths of the pre-formed twin ss-(dT) ${ }_{n}$ tails increase from zero to six nucleotides; however, $\Delta H_{\mathrm{obs}}$ remains unchanged at $(-64 \pm 3) \mathrm{kcal} \mathrm{mol}^{-1}$ for $n \geq 6$ nucleotides. A linear fit to the length dependence of $\Delta H_{\mathrm{obs}}$ for $n=0$ to 6 yields a value of -8 $( \pm 1) \mathrm{kcal} \mathrm{mol}^{-1}$. Therefore, the average enthalpic cost of melting one DNA base pair by RecBC is $(8 \pm 1) \mathrm{kcal} \mathrm{mol}^{-1} \mathrm{bp}^{-1}$.

\section{Discussion}

Previous studies of RecBCD binding to a blunt DNA duplex end have shown that the last four to five bp at the end of the duplex become accessible to $\mathrm{KMnO}_{4}$ attack in a $\mathrm{Mg}^{2+}$-dependent but ATP-independent manner ${ }^{35}$. The last four bp of a blunt ended duplex DNA are also observed to be unpaired in a crystal structure of a RecBCD-DNA complex formed in the presence of $\mathrm{Ca}^{2+27}$. Equilibrium binding studies performed in the absence of ATP also show that RecBCD binds tightest to a DNA end containing preexisting 3'-ss- $(\mathrm{dT})_{6}$ and 5' -ss-

$(\mathrm{dT})_{10}$ tails 37 . These observations indicate that RecBCD is capable of melting out the last four to six base pairs upon binding to a blunt duplex DNA end in a divalent cation-dependent, but ATP-independent reaction. Here we have shown that RecBC is also able to carry out a similar bp melting reaction upon binding a blunt-ended DNA.

\section{Base pair melting by $\mathrm{RecBC}$ is $\mathrm{Mg}^{2+}$-dependent}

Divalent cations such as $\mathrm{Mg}^{2+}$ can always compete with monovalent cations and protein for the binding of DNA and thus the presence of $\mathrm{Mg}^{2+}$ will generally decrease the equilibrium constant for protein binding to DNA and the magnitude of its dependence on $[\mathrm{NaCl}] 40 ; 41$. Although for RecBC binding to DNA I we observe that the dependence of the equilibrium constant $\left(K_{\mathrm{BC}, \mathrm{R}}\right)$ on $[\mathrm{NaCl}]$ is affected by the presence of $10 \mathrm{mM} \mathrm{MgCl}$, the effects are very different from those expected if $\mathrm{Mg}^{2+}$ only acted as a competitor. The fact that $K_{\mathrm{BC}, \mathrm{R}}$ measured in the presence of $\mathrm{Mg}^{2+}$ is always higher than $K_{\mathrm{BC}, \mathrm{R}}$ measured in the absence of $\mathrm{Mg}^{2+}$ at all $[\mathrm{NaCl}]$ examined indicates that $\mathrm{Mg}^{2+}$ facilitates RecBC binding to DNA. This $\mathrm{Mg}^{2+}$-dependent increase in $K_{\mathrm{BC}, \mathrm{R}}$ is consistent with the hypothesis that $\mathrm{RecBC}$ requires $\mathrm{Mg}^{2+}$ in order to melt a region of the duplex DNA end upon binding.

The effects of varying the lengths of the pre-existing tails on $K_{\mathrm{BC}}$ for the DNA IV and V series in the absence of $\mathrm{MgCl}_{2}$ are qualitatively similar to the effects observed in the presence of 10 $\mathrm{mM} \mathrm{MgCl} 2$. Therefore, these data by themselves cannot be used to conclude whether RecBC melts out six base pairs in a $\mathrm{Mg}^{2+}$-dependent manner. However, the quantitative differences between $K_{\mathrm{BC}}$ measured in the absence and presence of $\mathrm{MgCl}_{2}$ are consistent with the hypothesis that six base pairs at the blunt DNA end are melted out by RecBC only in the presence of $\mathrm{Mg}^{2+}$. For DNA ends with pre-existing $(\mathrm{dT})_{n}$ tails shorter than six nucleotides, the difference between $K_{\mathrm{BC}}$ measured in the presence and absence of $\mathrm{Mg}^{2+}$ is expected to increase in magnitude as the lengths of the pre-existing $(\mathrm{dT})_{n}$ tails decreases because the number of base pairs melted by RecBC $(6-n)$ increases as $n$ decreases. Indeed we observe that the magnitude 
of the difference between $K_{\mathrm{BC}}$ measured in the presence and absence of $10 \mathrm{mM} \mathrm{MgCl}_{2}$ decreases as the length of the pre-existing tail increases from zero to six nucleotides, whereas no difference was observed in $K_{\mathrm{BC}}$ for DNA possessing ss- $(\mathrm{dT})_{n}$ tails with $n \geq 6$ nucleotides. The $\mathrm{KMnO}_{4}$ footprinting data also directly shows a $\mathrm{Mg}^{2+}$-dependent melting by $\mathrm{RecBC}$ of at least four base pairs at the end of a blunt DNA end.

The effects of $\left[\mathrm{MgCl}_{2}\right]$ on the Cy3 fluorescence of DNA I through III molecules when prebound with RecBC also indicate that binding of $\mathrm{Mg}^{2+}$ by RecBC facilitates base pair melting at the end of DNA. The RecBC-DNA III complex, which possesses pre-existing twin ss$(\mathrm{dT})_{6}$ tails and therefore no melting is expected to occur upon binding of RecBC, failed to show an increase in the Cy3 fluorescence, whereas both RecBC-bound DNA I and II (with ss-DNA tails shorter than six nucleotides) exhibit an enhancement in $\mathrm{Cy} 3$ fluorescence upon titration of $\mathrm{MgCl}_{2}$ consistent with bp melting being associated with the fluorescence enhancement upon addition of $\mathrm{MgCl}_{2}$. The same final fluorescence level exhibited by all RecBC-DNA complexes at the end of titration indicating that all the RecBC-DNA complexes are in the same final state (i.e., six base pairs at the end are unpaired) at the end of titration.

\section{$\mathrm{Mg}^{2+}$ overcomes a kinetic barrier to facilitate base pair melting by RecBC}

For RecBC-induced melting of duplex DNA to occur, the favorable free energy change accompanying RecBC binding to DNA ( $\left.\Delta G^{\circ}{ }_{\text {bind }}\right)$ must be sufficient to overcome the unfavorable free energy change associated with base pair melting $\left(\Delta G^{\circ}\right.$ melt $)$. One potential explanation for the requirement of $\mathrm{Mg}^{2+}$ for this process is if $\mathrm{Mg}^{2+}$ increases the affinity of RecBC for the final fully melted DNA product so that $\left(\Delta G^{\circ}\right.$ ind $+\Delta G^{\circ}$ melt $\left.<0\right)$, whereas in the absence of $\mathrm{Mg}^{2+},\left(\Delta G^{\circ}\right.$ bind $+\Delta G^{\circ}$ melt $\left.>0\right)$. However, the fact that $\Delta G^{\circ}$ obs $\left(=-R T \ln K_{\mathrm{BC}}\right)$ for RecBC binding to a DNA end possessing pre-existing ss-(dT) ${ }_{n}$ tails with $n \geq 6$ nucleotides is the same with or without $10 \mathrm{mM} \mathrm{MgCl} 2$ indicates that there is already sufficient binding free energy available from the RecBC-DNA interaction even in the absence of $\mathrm{Mg}^{2+}$, to achieve a melted structure. Yet, bp melting by RecBC does not occur in the absence of $\mathrm{Mg}^{2+}$. Therefore, our results suggest that base pair melting by RecBC binding to DNA is thermodynamically favored in the presence and absence of $\mathrm{Mg}^{2+}$, but is kinetically blocked in the absence of $\mathrm{Mg}^{2+}$.

Interestingly, the $\mathrm{Cy} 3$ fluorescence data suggest that $\mathrm{Ca}^{2+}$ can also facilitate base pair melting by RecBC. This observation is consistent with the fact that four bp are unpaired in the RecBCDblunt-ended DNA crystal structure formed in the presence of $\mathrm{Ca}^{2+27}$. The one surprising observation is that the effect of $\mathrm{Ca}^{2+}$ is indistinguishable from $\mathrm{Mg}^{2+}$. Even if $\mathrm{Ca}^{2+}$ and $\mathrm{Mg}^{2+}$ bind to the same site to facilitate bp melting, it is not expected that they would have the same affinity for the same site on RecBC or the RecBC-DNA complex given the distinctly different ion sizes and requirements for $\mathrm{Ca}^{2+}$ and $\mathrm{Mg}^{2+}$ binding sites within proteins $47 ; 48$. In fact, $\mathrm{Ca}^{2+}$ is observed bound in the expected $\mathrm{Mg}^{2+}$ binding site within the RecB nuclease domain 27 and does inhibit the nuclease activity of RecBCD ${ }^{49}$. It is possible that there are multiple sites for $\mathrm{Mg}^{2+}$ and $\mathrm{Ca}^{2+}$ and that there is a fortuitous compensation of effects such that the apparent affinity of $\mathrm{Mg}^{2+}$ and $\mathrm{Ca}^{2+}$ appear to be the same. Since both $\mathrm{Ca}^{2+}$ and $\mathrm{Mg}^{2+}$ appear to function to relieve a kinetic block associated with DNA melting by RecBC and RecBCD, this could potentially mask any difference in affinity of these two ions for the RecBCD-DNA complex.

$\mathrm{ACa}^{2+}$ ion is observed bound at the $\mathrm{Mg}^{2+}$ binding site within the nuclease domain in the crystal structure of a RecBCD-DNA complex 27 . Yet, our data indicate that deletion of the nuclease domain to form $\operatorname{RecB}^{\Delta \text { nuc }} \mathrm{C}$, has no influence on the ability of $\mathrm{Mg}^{2+}$ to facilitate DNA melting by RecBC. Therefore the site for $\mathrm{Mg}^{2+}$ binding that facilitates bp melting by RecBC is not located on the nuclease domain of RecB. The ATP binding site on RecB is a potential site for binding $\mathrm{Mg}^{2+}$ but it is also possible that the $\mathrm{Mg}^{2+}$ binding site is present on the RecC subunit. 
The structural fold of $\mathrm{RecC}$ is similar to that of RecB and it has been suggested that $\mathrm{RecC}$ may have been a defunct RecB helicase 50 .

\section{Thermodynamics of RecBC-DNA complex formation and base pair melting}

We observe that $\Delta C_{\mathrm{p}, \text { obs }}$ for RecBC binding to a blunt DNA end in the presence of $\mathrm{Mg}^{2+}(-1.2$ $\left.\pm 0.2 \mathrm{kcal} \mathrm{mol}^{-1} \mathrm{~K}^{-1}\right)$ is very similar to the $\Delta C_{\mathrm{p}, \text { obs }}$ for RecBC binding to a DNA end possessing two pre-existing twin-(dT) 6 tails (DNA VI with $n=6$ nucleotides) $\left(-1.6 \pm 0.3 \mathrm{kcal} \mathrm{mol}^{-1}\right.$ $\mathrm{K}^{-1}$ in $10 \mathrm{mM} \mathrm{MgCl}_{2}$ and $-1.6 \pm 0.4 \mathrm{kcal} \mathrm{mol}^{-1} \mathrm{~K}^{-1}$ in no $\mathrm{MgCl}_{2}$ ). This similarity suggests that there is little heat capacity change associated with bp melting, at least as it occurs within the RecBC complex. This is consistent with the conclusion that unstacking of bases does not contribute significantly to the $\Delta C_{\mathrm{p}, \text { obs }}$ of duplex disruption ${ }^{51}$. In contrast, $\Delta C_{\mathrm{p}, \mathrm{obs}}$ for RecBC binding to blunt DNA end in the absence of $\mathrm{Mg}^{2+}$ is less negative $\left(-0.5 \pm 0.3 \mathrm{kcal} \mathrm{mol}^{-1}\right.$ $\mathrm{K}^{-1}$ ). The potential origins of the heat capacity change associated with any protein-DNA complex or any macromolecular interaction are numerous $52 ; 53 ; 54 ; 55 ; 56 ; 57$, and a determination of the origins of $\Delta C_{\mathrm{p}, \mathrm{obs}}$ for this system are beyond the scope of this work. Further studies are required to elucidate the linked equilibria responsible for the large and negative $\Delta C_{\mathrm{p}, \mathrm{obs}}$ for RecBC binding to DNA ends and the difference between $\Delta C_{\mathrm{p}, \mathrm{obs}}$ for the formation of the "melted" versus "un-melted" complexes.

We estimated the average enthalpic cost of melting six base pairs at a blunt DNA end by RecBC in the presence of $\mathrm{Mg}^{2+}$ from the measurements of $\Delta H_{\mathrm{obs}}$ for RecBC binding to a DNA end possessing pre-existing twin ss-(dT) ${ }_{n}$ tails (DNA VI) with $n$ varying from 0 to 6 nt. This estimate is based on two assumptions. The first is that the end state of a RecBC-DNA VI complex is the same for $0 \leq n \leq 6$ in the presence of $10 \mathrm{mM} \mathrm{MgCl}_{2}$, i.e. the last six base pairs are unpaired in $100 \%$ of the RecBC-DNA complexes. The second assumption is that $\Delta H_{\mathrm{obs}}$ is independent of base sequence and composition. With these assumptions, we estimate a value of $47 \pm 7 \mathrm{kcal} \mathrm{mol}^{-1}$ for the enthalpic cost to melt out the last six base pairs at the blunt DNA end used in our experiments, which consists of four $\mathrm{G} / \mathrm{C}$ and two $\mathrm{A} / \mathrm{T}$ base pairs. This corresponds to a value of $(8 \pm 1) \mathrm{kcal} \mathrm{mol}^{-1} \mathrm{bp}^{-1}$ for the average enthalpic cost of melting out one base pair at $25^{\circ} \mathrm{C}$. Since this estimate is based on the difference in $\Delta H_{\mathrm{obs}}$ for binding of a series of RecBC-DNA VI complexes, the contributions to $\Delta H_{\mathrm{obs}}$ from the RecBC-DNA interactions should cancel if the final RecBC-DNA complexes are the same and independent of base composition. Previous estimates of $\Delta H_{\mathrm{obs}}$ for base pair melting are: 4.3 to $9 \mathrm{kcal}$ $\mathrm{mol}^{-1} \mathrm{bp}^{-158}, 5.2$ to $15 \mathrm{kcal} \mathrm{mol}^{-1} \mathrm{bp}^{-151}$ and $\sim 7 \mathrm{kcal} \mathrm{mol}^{-1} \mathrm{bp}^{-1}$ from the nearest neighbor model ${ }^{59}$. Our value of $(8 \pm 1) \mathrm{kcal} \mathrm{mol}^{-1} \mathrm{bp}^{-1}$ falls within this range. Since determinations of $\Delta H_{\text {obs }}$ for base pair melting from DNA melting experiments is generally difficult due to the uncertainties associated with obtaining accurate baselines at low and high temperatures, our determination may represent a more accurate estimate of this average quantity.

\section{Implications for the helicase mechanism of RecBC and RecBCD}

We have shown that when RecBC binds the end of a blunt-ended DNA, it melts out six base pairs at the DNA end in a $\mathrm{Mg}^{2+}$-dependent but ATP-independent manner. Our results suggest that $\mathrm{Mg}^{2+}$ functions by overcoming a kinetic barrier to the RecBC-mediated DNA melting process. The binding of RecBCD to a blunt DNA end also results in the unpairing of the last 4 to 5 base pairs at the end of the duplex DNA ${ }^{35}$. The number of base pairs melted out by RecBCD upon binding to a blunt DNA end is very similar to the "kinetic step size" of $3.9 \pm$ $0.6 \mathrm{bp} \mathrm{s}^{-1}$ estimated for RecBCD unwinding of DNA from pre-steady state kinetic studises of DNA $31 ; 32 ; 33$. Recall that a kinetic unwinding step size of 4 bp indicates that some ratelimiting step in the unwinding process is repeated every 4 bp on average during the unwinding process. The similarity between these two values suggests that DNA unwinding by RecBCD may occur in a two-step process in which 4-6 base pairs of DNA are melted upon binding of RecBCD to the duplex region independent of ATP, followed by more rapid ATP-dependent 
translocation of RecBCD to the newly formed ss/dsDNA junction 31; 32; 33 . Since RecBC also melts out base pairs upon binding to a duplex DNA end, it is possible that RecBC also unwinds DNA by this same mechanism, such that the RecBC binding alone is sufficient to actively open the next $4 \mathrm{bp}$.

\section{Materials and Methods}

\section{Buffers}

Buffers were made from reagent grade chemicals using double-distilled water that was further deionized with a Milli-Q purification system (Millipore Corp., Bedford, MA). Buffer C contains $20 \mathrm{mM}$ potassium phosphate (pH 6.8), $0.1 \mathrm{mM}$ 2-mercaptoethanol (2-ME), $0.1 \mathrm{mM}$ EDTA, $10 \%$ (v/v) glycerol. Buffer M contains $20 \mathrm{mM}$ MOPS-KOH (pH 7.0), 1 mM 2-ME, $5 \%(\mathrm{v} / \mathrm{v})$ glycerol. The concentration of $\mathrm{MgCl}_{2}$ stocks was determined by measuring the refractive index of a stock solution in water using a Mark II refractometer (Leica Inc., Buffalo, $\mathrm{NY}$ ) and a standard table relating refractive index to $\left[\mathrm{MgCl}_{2}\right]{ }^{60}$.

\section{Proteins}

E. coli RecB and RecC proteins were purified and reconstituted to form RecBC as described 32. $\mathrm{RecB}^{\Delta \text { nuc }}$ was purified and reconstituted with $\operatorname{RecC}$ to form $\operatorname{RecB}^{\Delta \mathrm{nuc} C} \mathrm{C}$ as described ${ }^{61}$. RecBC and $\operatorname{RecB}^{\Delta \text { nuc }} \mathrm{C}$ concentrations were determined spectrophotometrically in buffer $\mathrm{C}$ using extinction coefficients of $\varepsilon_{280}=3.9 \times 10^{5} \mathrm{M}^{-1} \mathrm{~cm}^{-132}$ and $\varepsilon_{280}=3.4 \times 10^{5} \mathrm{M}^{-161}$, respectively. All protein concentrations reported refer to the $\operatorname{RecBC}$ or $\operatorname{RecB}{ }^{\Delta \text { nuc }} \mathrm{C}$ heterodimer. Bovine serum albumin (BSA) was from Roche (Indianapolis, IN) and its concentration was determined using an extinction coefficient of $\varepsilon_{280}=4.3 \times 10^{4} \mathrm{M}^{-1} \mathrm{~cm}^{-1}$ in buffer $\mathrm{C}^{37}$. All proteins were dialyzed into the particular reaction buffer before use. Dialyzed RecBC or $\operatorname{Rec} B^{\Delta \text { nuc }} \mathrm{C}$ were stored at $4^{\circ} \mathrm{C}$ for up to five days, since a loss of activity ( $\sim 15 \%$ ) was observed after five days at $4^{\circ} \mathrm{C}$.

\section{Oligodeoxynucleotides}

Oligodeoxynucleotides were synthesized using an ABI model 391 synthesizer (Applied Biosystems, Foster City, CA) using reagents and phosphoramidites from Glen Research (Sterling, VA). A first purification step of each single-stranded oligodeoxynucleotide was performed using polyacrylamide gel electrophoresis under denaturing conditions followed by removal of the DNA from the gel by electroelution 62 . The resulting oligodeoxynucleotides were then further purified chromatographically by reverse phase HPLC using an XTerra MS C18 column (Waters, Milford, MA). The concentration of each DNA strand was determined by completely digesting the strand with phosphodiesterase I (Worthington, Lakewood, NJ) in $100 \mathrm{mM}$ Tris- $\mathrm{Cl} \mathrm{pH} \mathrm{9.2,3} \mathrm{mM} \mathrm{MgCl}_{2}$, at $25^{\circ} \mathrm{C}$ and measuring the absorbance of the resulting mixture of mononucleotides at $260 \mathrm{~nm}$ as described ${ }^{51}$. The extinction coefficients at $260 \mathrm{~nm}$ used in this analysis are: $15340 \mathrm{M}^{-1} \mathrm{~cm}^{-1}$ for AMP, $7600 \mathrm{M}^{-1} \mathrm{~cm}^{-1}$ for CMP, $12160 \mathrm{M}^{-1}$ $\mathrm{cm}^{-1}$ for GMP, $8700 \mathrm{M}^{-1} \mathrm{~cm}^{-1}$ for TMP 63 and $5000 \mathrm{M}^{-1} \mathrm{~cm}^{-1}$ for Cy3 (Glenn Research). Duplex DNA substrates were prepared by mixing equimolar concentrations (usually $3 \mu \mathrm{M}$ ) of the appropriate DNA strands in reaction buffer, which was subsequently heated to $90^{\circ} \mathrm{C}$ for five minutes followed by slow cooling to $25^{\circ} \mathrm{C}$. Reference DNA I (Figure 1a) was formed from strands $\mathbf{1}$ and $\mathbf{2}$ (Figure 1c); reference DNA II was formed from strands $\mathbf{3}$ and $\mathbf{4}$; reference DNA III was formed from strands $\mathbf{5}$ and $\mathbf{6}$; competitor DNA series IV was formed from strands $\mathbf{7}$ and $\mathbf{8}$; competitor DNA series $\mathbf{V}$ was formed from strands $\mathbf{9}$ and 10; and competitor DNA series VI was formed from strands $\mathbf{1 1}$ and $\mathbf{1 2}$. The sequences of the oligodeoxynucleotides used in this study are given in Figure 1c. 


\section{Fluorescence Titrations}

Fluorescence titrations were performed as described ${ }^{37}$ using a PTI QM-4 fluorometer (Photon Technology International, Lawrenceville, NJ) equipped with a 75 watt Xe lamp. All slit widths were set at $0.5 \mathrm{~mm}$. The temperature of sample in the $10-\mathrm{mm}$ pathlength Type 3 quartz fluorometer cuvette ( $3 \mathrm{~mL}$ ) (NSG Precision Cells Inc., Farmingdale, NY) was controlled using a Lauda RM6 recirculation water bath (Brinkmann, Westbury, NY). Stirring was maintained throughout each experiment using a P-73 cylindrical cell stirrer with a diameter of $8 \mathrm{~mm}$ (NSG Precision Cells Inc., Farmingdale, NY). The corrected Cy3 fluorescence intensity $\left(F_{i, \text { corr }}\right)$ after the $i$-th addition of protein and the initial corrected Cy3 fluorescence of the reference DNA $\left(F_{0, \text { corr }}\right)$ were obtained as described previously ${ }^{37}$. Briefly, $F_{i, \text { corr }}$ is defined as in equation (1):

$$
F_{i, \mathrm{corr}}=\left(F_{i}-F_{\mathrm{b}}\right) \frac{V_{i}}{V_{0}}
$$

where $F_{i}$ is the fluorescence intensity after the $i$-th addition of titrant, $F_{\mathrm{b}}$ is the background fluorescence of the buffer which is always negligible ${ }^{37}, V_{i}$ is the volume of the $i$-th addition and $V_{0}$ is the volume before the first addition.

The observed relative fluorescence change $\left(\Delta F_{\mathrm{obs}}\right)$ is defined as in equation (2),

$$
\Delta F_{\text {obs }}=\frac{F_{i, \text { corr }}-F_{0, \text { corr }}}{F_{0, \text { corr }}}
$$

$\Delta F_{\text {obs }}$ reaches its maximum value $\left(\Delta F_{\max }\right)$ when both ends of the reference DNA are bound with protein. Hence $\Delta F_{\text {obs }} / \Delta F_{\max }\left(0 \leq F_{\text {obs }} / \Delta F_{\max } \leq 1\right)$ equals the average of protein molecules bound per DNA end, and thus the average number of protein molecules bound per DNA molecule is given by $\left(2 \Delta F_{\text {obs }} / \Delta F_{\max }\right)$.

\section{"Salt-back" titrations}

"Salt-back" titrations 44; 64 were performed after completion of a regular titration, i.e., after all additions of RecBC have been made. A buffer containing the same components as the reaction buffer but with $4 \mathrm{M} \mathrm{NaCl}$ was titrated into to the cuvettes and fluorescence measurements were made as described above. Data from "salt-back" titration experiments were analyzed using the same model used to describe the binding of RecBC to the ends of reference DNA, which has been described in detail ${ }^{37}$. In this model, RecBC (hereafter referred to as B) binds to each end of reference DNA (D) with the same binding constant, $K_{R}$, because the reference DNA has nearly identical ends. The binding polynomial for this model, which has two independent and identical sites, is given in equation (3),

$$
P=1+2 K_{\mathrm{R}} \mathrm{B}_{\mathrm{f}}+K_{\mathrm{R}}^{2} \mathrm{~B}_{\mathrm{f}}^{2}
$$

where $B_{f}$ is the free concentration of protein.

The average number of protein molecules bound per DNA molecule is given by equation (4),

$$
\frac{\mathrm{B}_{\text {bound }}}{\mathrm{D}_{\mathrm{T}}}=\frac{2 K_{R} \mathrm{~B}_{\mathrm{f}}}{1+K_{R} \mathrm{~B}_{\mathrm{f}}}=2 \frac{\Delta F_{\text {obs }}}{\Delta F_{\max }}
$$

where $B_{\text {bound }}=\left([D B]+2\left[B_{2} D\right]\right),[D B]$ is the concentration of $D$ with only one of its ends bound by $B$ and $\left[\mathrm{B}_{2} \mathrm{D}\right]$ is the concentration of $\mathrm{D}$ with both of its ends bound by $\mathrm{B}$.

As described previously $37, \Delta F_{\text {obs }} / \Delta F_{\max }$ can be expressed explicitly in terms of total protein concentration $\left(\mathrm{B}_{\mathrm{T}}\right)$, total reference DNA concentration $\left(\mathrm{D}_{\mathrm{T}}\right)$ and $K_{\mathrm{R}}$ as in equation (5). 


$$
\frac{\Delta F_{\text {obs }}}{\Delta F_{\max }}=\frac{1+K_{\mathrm{R}}\left(\mathrm{B}_{\mathrm{T}}+2 \mathrm{D}_{\mathrm{T}}\right)-\sqrt{4 K_{\mathrm{R}} \mathrm{B}_{\mathrm{T}}+\left(1-K_{\mathrm{R}} \mathrm{B}_{\mathrm{T}}+2 K_{\mathrm{R}} \mathrm{D}_{\mathrm{T}}\right)^{2}}}{4 K_{\mathrm{R}} \mathrm{D}_{\mathrm{T}}}
$$

Experimental fluorescence titrations, plotted as $\Delta F_{\text {obs }}$ Vs. [ $\left.\mathrm{B}_{\mathrm{T}}\right]$, were obtained at three different reference DNA concentrations, $\mathrm{D}_{\mathrm{T}}$, and analyzed by global non-linear least squares (NLLS) analysis using equation (5) to obtain the best fit values of $K_{\mathrm{R}}$ and $\Delta F_{\max }$.

To calculate $K_{\mathrm{R}}$ at each [ $\left.\mathrm{NaCl}\right]$ during a "salt-back" titration, equation (5) is rearranged and $\Delta F_{\text {obs }}$ is substituted using equation (2) to become equation (6),

$$
K_{\mathrm{R}}=\frac{\frac{\Delta F_{\mathrm{obs},[\mathrm{NaCl}]}}{\Delta F_{\max }}}{\left(\frac{\Delta F_{\mathrm{obs},[\mathrm{NaCl}]}}{\Delta F_{\max }}-1\right)\left(2 \mathrm{D}_{\mathrm{T}} \frac{\Delta F_{\mathrm{obs},[\mathrm{NaCl}]}}{\Delta F_{\max }}-\mathrm{B}_{\mathrm{T}}\right)}
$$

where $\Delta F_{\text {obs, }[\mathrm{NaCl}]}$ is the relative fluorescence change observed after each addition of $\mathrm{NaCl}$ and $\Delta F_{\max }$ is determined previously from an independent titration experiment of reference DNA with RecBC.

\section{Competition methods to determine equilibrium binding to non-fluorescent DNA}

Equilibrium constants for RecBC binding to non-fluorescent DNA molecules (N) were obtained from analysis of competition binding studies 65 . The analysis of competition data has been described previously 37 and the same analysis is used here. Briefly, three separate titration experiments were performed at three different non-fluorescent competitor DNA concentrations $\left(\mathrm{N}_{1}, \mathrm{~N}_{2}\right.$ or $\left.\mathrm{N}_{3}\right)$. In each titration experiment, a constant concentration of competitor DNA $\left(\mathrm{N}_{1}, \mathrm{~N}_{2}\right.$ or $\left.\mathrm{N}_{3}\right)$ was added to a cuvette containing a Cy3 labeled reference DNA at $20 \mathrm{nM}$ and then titrated with protein. Since the competitor DNA molecules used here have nearly identical ends (DNA IV and V), B should bind to both ends of $\mathrm{N}$ with binding constant $K_{\mathrm{N}}$. Then $\mathrm{B}_{\mathrm{T}}$ and $\mathrm{B}_{\mathrm{f}}$ can be related to the total concentration of non-fluorescent DNA concentration $\left(\mathrm{N}_{\mathrm{T}}\right)$, $K_{\mathrm{N}}, K_{\mathrm{R}}$ and $\mathrm{D}_{\mathrm{T}}$ as shown in equation (7),

$\mathrm{B}_{\mathrm{T}}=\mathrm{B}_{\mathrm{f}}\left(1+2\left(\frac{K_{\mathrm{N}} \mathrm{N}_{\mathrm{T}}}{\left(1+K_{\mathrm{N}} \mathrm{B}_{\mathrm{f}}\right)^{2}}+\frac{K_{\mathrm{R}} \mathrm{D}_{\mathrm{T}}}{\left(1+K_{\mathrm{R}} \mathrm{B}_{\mathrm{f}}\right)^{2}}\right)+2 \mathrm{~B}_{\mathrm{f}}\left(\frac{K_{\mathrm{N}}^{2} \mathrm{~N}_{\mathrm{T}}}{\left(1+K_{\mathrm{N}} \mathrm{B}_{\mathrm{f}}\right)^{2}}+\frac{K_{\mathrm{R}}^{2} \mathrm{D}_{\mathrm{T}}}{\left(1+K_{\mathrm{R}} \mathrm{B}_{\mathrm{f}}\right)^{2}}\right)\right)$

Data from the three titration experiments at competitor DNA concentrations $\mathrm{N}_{1}, \mathrm{~N}_{2}$ and $\mathrm{N}_{3}$ were analyzed simultaneously using equations (4) and (7) and the "implicit fitting" NLLS algorithm in Scientist (Micromath, St Louis, MO) without the need to obtain an explicit expression for $\mathrm{B}_{\mathrm{f}}$. The value of $K_{\mathrm{N}}$ was allowed to float in this analysis while the values of $K_{\mathrm{R}}$ and $\Delta F_{\max }$ were fixed at values determined from the analysis of independent titrations with reference DNA in the absence of competitor. The uncertainties for the independently determined values of $K_{\mathrm{R}}$ and $\Delta F_{\max }$ were propagated into the reported uncertainties in $K_{\mathrm{N}}$.

\section{Equilibrium binding of $\mathbf{M g}^{2+}$ to $\mathrm{RecBC}$ and RecBC-Reference DNA complex}

The $\mathrm{MgCl}_{2}$ titration data were analyzed by assuming there is one $\mathrm{Mg}^{2+}$-binding site on $\mathrm{RecBC}$ as well as RecBC bound at one end of the reference DNA and no significant binding of $\mathrm{Mg}^{2+}$ ions to the reference DNA. This model is sufficient in describing the data (Figure 5a) and therefore we did not consider more complicated models involving more than one $\mathrm{Mg}^{2+}$ binding site per RecBC. This one- $\mathrm{Mg}^{2+}$-site model is represented in Scheme 1, where $K_{1, \text { no } \mathrm{Mg}}$ and $K_{1}$ are the stepwise macroscopic binding constants for forming BD (D with only one of its ends bound by $\mathrm{B}$ ) in the absence and presence of $\mathrm{MgCl}_{2}$, respectively, while $K_{2, \text { no } \mathrm{Mg}}$ and $K_{2}$ are the stepwise macroscopic 


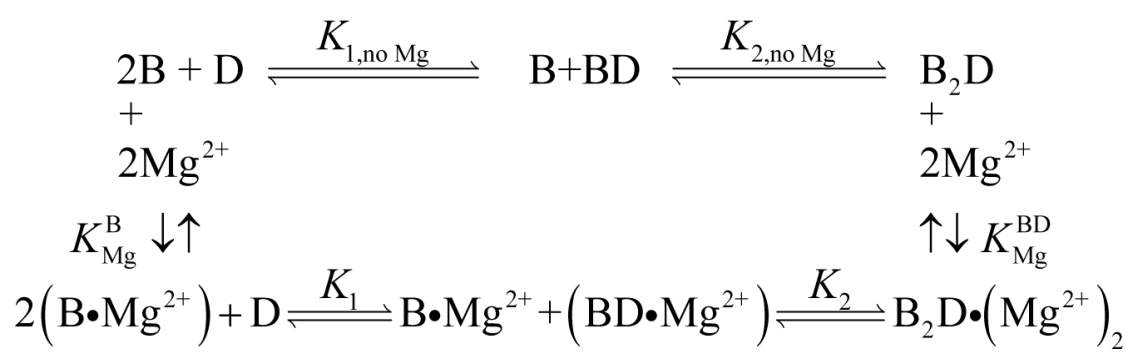

Scheme 1.

binding constants for forming $\mathrm{B}_{2} \mathrm{D}$ ( $\mathrm{D}$ with both of its ends bound by $\mathrm{B}$ ) in the absence and presence of $\mathrm{MgCl}_{2}$, respectively. The equilibrium constant of $\mathrm{B}$ binding to $\mathrm{D}$ in the presence of $\mathrm{Mg}^{2+}\left(K_{\mathrm{R}}\right)$ is related to $K_{1}$ and $K_{2}$ as described in equation (8),

$$
K_{1}=2 K_{\mathrm{R}} \text { and } K_{2}=K_{\mathrm{R}} / 2
$$

Similarly, $K_{1, \text { no Mg }}$ and $K_{2, \text { no Mg }}$ can be expressed in terms of equilibrium constant for B binding to $\mathrm{D}$ in the absence of $\mathrm{Mg}^{2+}\left(K_{\mathrm{R}, \mathrm{no} \mathrm{Mg}}\right)$ as given in equation (9):

$$
K_{1, \text { no }} \quad{ }_{\mathrm{Mg}}=2 K_{\mathrm{R}, \mathrm{no}} \quad \mathrm{Mg} \quad \text { and } K_{2, \mathrm{no}} \quad \mathrm{Mg}_{\mathrm{R}, \mathrm{no}} \quad \mathrm{Mg} / 2
$$

$K_{\mathrm{Mg}}^{\mathrm{B}}$ is the equilibrium constant for one molecule of $\mathrm{B}$ binding to one $\mathrm{Mg}^{2+}$ ion while $K_{\mathrm{Mg}}^{\mathrm{BD}}$ is the equilibrium constant for one molecule of $\mathrm{B}$ bound at one end of $\mathrm{D}$ binding to one $\mathrm{Mg}^{2+}$ ion. Expressions for $\mathrm{B}_{\mathrm{T}}, \mathrm{D}_{\mathrm{T}}$ and total $\mathrm{Mg}^{2+}$ concentration $\left(\mathrm{Mg}_{\mathrm{T}}\right)$ in terms of $\mathrm{B}_{\mathrm{f}}, \mathrm{D}_{\mathrm{f}}$, free $\mathrm{Mg}^{2+}$ concentration $\left(\mathrm{Mg}_{\mathrm{f}}\right), K_{\mathrm{R}}, K_{\mathrm{R}, \mathrm{no} \mathrm{Mg}}, K_{\mathrm{Mg}}^{\mathrm{B}}$ and $K_{\mathrm{Mg}}^{\mathrm{BD}}$ are given in equations (10), (11) and (12) respectively:

$$
\begin{gathered}
\mathrm{B}_{\mathrm{T}}=\mathrm{B}_{\mathrm{f}}\left(1+K_{\mathrm{Mg}}^{\mathrm{B}} \mathrm{Mg}_{\mathrm{f}}+2\left(K_{\mathrm{R}} K_{\mathrm{Mg}}^{\mathrm{B}}+K_{\mathrm{R}, \text { no }} \quad \mathrm{Mg}_{\mathrm{Mg}}\right) \mathrm{D}_{\mathrm{f}}+2 \mathrm{~B}_{\mathrm{f}} \mathrm{D}_{\mathrm{f}} K_{\mathrm{R}, \text { no }}^{2} \quad{ }_{\mathrm{Mg}}\left(1+K_{\mathrm{Mg}}^{\mathrm{BD}} \mathrm{Mg}_{\mathrm{f}}\right)^{2}\right) \\
\mathrm{D}_{\mathrm{T}}=\mathrm{D}_{\mathrm{f}}\left(1+2 \mathrm{~B}_{\mathrm{f}}\left(K_{\mathrm{R}} K_{\mathrm{Mg}}^{\mathrm{B}} \mathrm{Mg}_{\mathrm{f}}+K_{\mathrm{R}, \text { no }} \quad \mathrm{Mg}^{2}\right)+\mathrm{B}_{\mathrm{f}}^{2} K_{\mathrm{R}, \text { no }}^{2} \quad{ }_{\mathrm{Mg}}\left(1+K_{\mathrm{Mg}}^{\mathrm{BD}} \mathrm{Mg}_{\mathrm{f}}\right)^{2}\right) \\
\mathrm{Mg}_{\mathrm{T}}=\mathrm{Mg}_{\mathrm{f}}\left(1+K_{\mathrm{Mg}}^{\mathrm{B}} \mathrm{B}_{\mathrm{f}}\left(1+2 K_{\mathrm{R}} \mathrm{D}_{\mathrm{f}}\right)+2 K_{\mathrm{R}, \text { no }}^{2} \quad{ }_{\mathrm{Mg}} \mathrm{B}_{\mathrm{f}}^{2} \mathrm{D}_{\mathrm{f}}\left(1+K_{\mathrm{Mg}}^{\mathrm{BD}} \mathrm{Mg}_{\mathrm{f}}\right)\right)
\end{gathered}
$$

In our experiment, since all the reference DNA molecules were bound with two molecules of RecBC before addition of $\mathrm{Mg}^{2+},[\mathrm{BD}]=[\mathrm{BD}] \cdot \mathrm{Mg}^{2+}=0$ and $\mathrm{D}_{\mathrm{T}}=\left[\mathrm{B}_{2} \mathrm{D}\right]+\left[\mathrm{B}_{2} \mathrm{D}\right] \cdot \mathrm{Mg}^{2+}+$ $\left[\mathrm{B}_{2} \mathrm{D}\right] \cdot\left(\mathrm{Mg}^{2+}\right)_{2}$. Therefore equations (10) to (12) become equations (13) to (15):

$$
\begin{gathered}
\mathrm{B}_{\mathrm{T}}=\mathrm{B}_{\mathrm{f}}\left(1+K_{\mathrm{Mg}}^{\mathrm{B}} \mathrm{Mg}_{\mathrm{f}}\right)+2 \mathrm{D}_{\mathrm{T}} \\
\mathrm{D}_{\mathrm{T}}=\mathrm{D}_{\mathrm{f}} \mathrm{B}_{\mathrm{f}}^{2} K_{\mathrm{R}, \text { no }}^{2}{ }_{\mathrm{Mg}}\left(1+K_{\mathrm{Mg}}^{\mathrm{BD}} \mathrm{Mg}_{\mathrm{f}}\right)^{2} \\
\mathrm{Mg}_{\mathrm{T}}=\mathrm{Mg}_{\mathrm{f}}\left(1+K_{\mathrm{Mg}}^{\mathrm{B}} \mathrm{B}_{\mathrm{f}}+2 K_{\mathrm{R}, \text { no }}^{2}{ }_{\mathrm{Mg}} K_{\mathrm{Mg}}^{\mathrm{BD}} \mathrm{B}_{\mathrm{f}}^{2} \mathrm{D}_{\mathrm{f}}\left(1+K_{\mathrm{Mg}}^{\mathrm{BD}} \mathrm{Mg}_{\mathrm{f}}\right)\right)
\end{gathered}
$$

By combining equations (13) through (15), one obtains equation (16),

$$
\mathrm{Mg}_{\mathrm{T}}=\mathrm{Mg}_{\mathrm{f}}\left(1+\frac{K_{\mathrm{Mg}}^{\mathrm{B}}\left(\mathrm{B}_{\mathrm{T}}-2 \mathrm{D}_{\mathrm{T}}\right)}{1+K_{\mathrm{Mg}}^{\mathrm{B}} \mathrm{Mg}_{\mathrm{f}}}+\frac{2 K_{\mathrm{Mg}}^{\mathrm{BD}} \mathrm{D}_{\mathrm{T}}}{1+K_{\mathrm{Mg}}^{\mathrm{BD}} \mathrm{Mg}_{\mathrm{f}}}\right)
$$

which relates $\mathrm{Mg}_{\mathrm{T}}$ to $\mathrm{Mg}_{\mathrm{f}}, \mathrm{B}_{\mathrm{T}}, \mathrm{D}_{\mathrm{T}}, K_{\mathrm{Mg}}^{\mathrm{B}}$ and $K_{\mathrm{Mg}}^{\mathrm{BD}}$.

$\Delta F_{\mathrm{obs},[\mathrm{Mg}]}$ in this experiment reaches its maximum value $\left(\Delta F_{\max ,[\mathrm{Mg}]}\right)$ when $\mathrm{Mg}^{2+}$ ions are bound at both ends of $\mathrm{B}_{2} \mathrm{D}$ to form $\mathrm{B}_{2} \mathrm{D} \cdot\left(\mathrm{Mg}^{2+}\right)_{2}$. Hence, $\Delta F_{\text {obs, }[\mathrm{Mg}]} / \Delta F_{\max ,[\mathrm{Mg}]}(0 \leq$ 
$\left.\Delta F_{\text {obs, }[\mathrm{Mg}]} / \Delta F_{\max ,[\mathrm{Mg}]} \leq 1\right)$ equals the average number of $\mathrm{Mg}^{2+}$ ions bound per RecBC-bound DNA end. The average number of $\mathrm{Mg}^{2+}$ ions bound per RecBC-saturated DNA molecule is given by equation (17):

$$
\frac{\mathrm{Mg}_{\text {bound }}}{\mathrm{D}_{\mathrm{T}}}=\frac{2 K_{\mathrm{Mg}}^{\mathrm{BD}} \mathrm{Mg}_{\mathrm{f}}}{1+K_{\mathrm{Mg}}^{\mathrm{BD}} \mathrm{Mg}_{\mathrm{f}}}=2 \frac{\Delta F_{\text {obs },[\mathrm{Mg}]}}{\Delta F_{\text {max },[\mathrm{Mg}]}}=2 \frac{F_{i, \mathrm{corr},[\mathrm{Mg}]}-F_{0, \text { corr },[\mathrm{Mg}]}}{F_{\text {max }, \text { corr },[\mathrm{Mg}]}-F_{0, \text { corr },[\mathrm{Mg}]}}
$$

where $\mathrm{Mg}_{\text {bound }}=2\left(\left[\mathrm{~B}_{2} \mathrm{D} \bullet\left(\mathrm{Mg}^{2+}\right)\right]+\left[\mathrm{B}_{2} \mathrm{D} \bullet\left(\mathrm{Mg}^{2+}\right)_{2}\right]\right), F_{i, \text { corr, }[\mathrm{Mg}]}$ is the corrected fluorescence intensity after the $i$-th addition of $\mathrm{Mg}^{2+}, F_{0 \text {,corr, }[\mathrm{Mg}]}$ is the corrected fluorescence intensity before the addition of $\mathrm{Mg}^{2+}$ and $F_{\text {max,corr, }[\mathrm{Mg}]}$ is the maximum value reached by $F_{i, \mathrm{cor},[\mathrm{Mg}]}$ after $\mathrm{Mg}^{2+}$ ions are bond at both ends of $\mathrm{B}_{2} \mathrm{D}$. Data were analyzed using equations (16) and (17) and the "implicit fitting" NLLS algorithm in Scientist (Micromath, St. Louis, MO) without the need to obtain an explicit expression for $\mathrm{Mg}_{\mathrm{f}}$. In this analysis, the values of $K_{\mathrm{Mg}}^{\mathrm{BD}}, K_{\mathrm{Mg}}^{\mathrm{B}}$ and $F_{\max , \text { corr,[Mg] }}$ were allowed to float. All uncertainties are reported at the $68 \%$ confidence limit ( \pm one standard deviation).

\section{Isothermal titration calorimetry}

ITC experiments were performed in a VP-ITC calorimeter (Microcal, Northampton, MA) as described $^{37}$. The analysis of the calorimetric data has been described in detail ${ }^{37}$ and the same analysis is used here. Briefly, experiments were carried out by titrating RecBC (0.7 to $1.1 \mu \mathrm{M}$ in the sample cell) with $10 \mu \mathrm{L}$ aliquots of DNA ( 8 to $14 \mu \mathrm{M}$ in the syringe) at four-minute intervals and at a stirring rate of $140 \mathrm{rpm}$. All samples were degassed prior to use. The heat of reaction was obtained by integration of the peak obtained after each injection of titrant, using the software (Origin 7.0) provided by the manufacturer. Separate control experiments were performed to determine the heat of dilution for each injection by injecting the same volumes of DNA into the sample cell containing only buffer. The observed heat for the $i$-th injection $\left(\Delta Q_{i}\right.$ ) was obtained after correcting for the heat of dilution as described 66 and is related to the total heat after the $i$-th injection $\left(Q_{i}^{\text {tot }}\right)$ as in equation (18):

$$
\Delta Q_{i}=Q_{i}^{\mathrm{tot}}-Q_{i-1}^{\mathrm{tot}}+\frac{\mathrm{d} V_{i}}{2 V_{0}}\left(Q_{i}^{\mathrm{tot}}+Q_{i-1}^{\mathrm{tot}}\right)
$$

where $\mathrm{d} V_{i}$ is the volume of the $i$-th injection and $V_{0}$ is the active cell volume $(1.43 \mathrm{~mL})$. Since the DNA molecules used here have nearly identical ends (DNA VI series in Figure 1a), the same model of two identical and independent sites (see equation (7)) was used to analyze $Q_{i}^{\text {tot }}$, as given by equation (19):

$$
\begin{aligned}
Q_{i}^{\mathrm{tot}} & =\Delta H_{\mathrm{obs}} V_{0} \mathrm{D}_{i}^{\mathrm{T}} \frac{2 K_{\mathrm{N}} \mathrm{B}_{i}^{\mathrm{f}}}{1+K_{\mathrm{N}} \mathrm{B}_{i}^{\mathrm{f}}} \\
& =\Delta H_{\mathrm{obs}} V_{0} \mathrm{D}_{i}^{\mathrm{T}} \frac{1+K_{\mathrm{N}}\left(\mathrm{B}_{i}^{\mathrm{T}}+2 \mathrm{D}_{i}^{\mathrm{T}}\right)-\sqrt{4 K_{\mathrm{N}} \mathrm{B}_{i}^{\mathrm{T}}+\left(1-K_{\mathrm{N}} \mathrm{B}_{i}^{\mathrm{T}}+2 K_{\mathrm{N}} \mathrm{D}_{i}^{\mathrm{T}}\right)^{2}}}{2 K_{\mathrm{N}} \mathrm{D}_{i}^{\mathrm{T}}}
\end{aligned}
$$

where $\Delta H_{\mathrm{obs}}$ is the observed enthalpy change for RecBC binding to one end of DNA, $\mathrm{D}_{i}^{\mathrm{T}}$ is the total DNA concentration in the cell after the $i$-th injection, $K_{\mathrm{N}}$ is the binding constant for RecBC binding to one DNA end and $\mathrm{B}_{i}{ }^{\mathrm{f}}$ and $\mathrm{B}_{i}{ }^{\mathrm{T}}$ are the concentrations of free and total RecBC, respectively, in the cell after the $i$-th injection. $\Delta H_{\mathrm{obs}}$ and $K_{\mathrm{N}}$ were obtained from NLLS analysis using equations (18) and (19) and the ITC NLLS algorithm contained within the Origin 7.0 software as described 66 .

In Figure 6a and $\mathrm{b}$, the observed heat released upon the $i$-th injection normalized to the amount of injected DNA ( $\left.\Delta Q_{i, \text { norm }}\right)$ is obtained using equation (20):

$$
\Delta Q_{i, \text { norm }}=\frac{\Delta Q_{i}}{\mathrm{~d} V_{i} \mathrm{D}^{\mathrm{T}}}
$$


where $\mathrm{D}^{\mathrm{T}}$ is the concentration of DNA in the syringe. The continuous lines in Figure $6 \mathrm{a}$ and $\mathrm{b}$ are simulations based on equations (18) to (20) and the best fit values of $\Delta H_{\mathrm{obs}}$ (Table 4) and $K_{\mathrm{N}}$ indicated in the figure legends.

Observed heat capacity change ( $\Delta C_{\mathrm{p}, \mathrm{obs}}$ ) was obtained from a linear regression of $\Delta H_{\mathrm{obs}}$ obtained at different temperature using equation (21),

$$
\Delta H_{\mathrm{obs}}=\Delta H_{\mathrm{obs}, \mathrm{ref}}+\Delta C_{\mathrm{p}, \mathrm{obs}}\left(T-T_{\mathrm{ref}}\right)
$$

where $\Delta H_{\text {obs,ref }}$ is the observed enthalpy change at some reference temperature $\left(T_{\text {ref }}\right)$. The dependence of $K_{\mathrm{BC}}$ on temperature is described by the van't Hoff equation $\partial \ln K_{\mathrm{BC}} / \partial(1 / T=$ $-\delta H_{\mathrm{obs}} / R$, where $R$ is the gas constant. By substituting equation (21) into the van't Hoff equation and integrating it between $T_{\text {ref }}$ to $T$, one can express $\ln K_{\mathrm{BC}}$ in terms of $\ln K_{\mathrm{BC}, \text { ref }}, \Delta H_{\mathrm{obs}, \text { ref, }}$, $\Delta C_{\mathrm{p}, \mathrm{obs}}, T_{\mathrm{ref}}$ and $T$ as shown in equation (22),

$\ln K_{\mathrm{BC}}=\ln K_{\mathrm{BC}, \text { ref }}+\frac{\Delta C_{\mathrm{p}, \mathrm{obs}} T_{\mathrm{ref}}-\Delta H_{\mathrm{obs}, \text { ref }}}{R}\left(\frac{1}{T}-\frac{1}{T_{\text {ref }}}\right)+\frac{\Delta C_{\mathrm{p}, \mathrm{obs}}}{R} \ln \frac{T}{T_{\text {ref }}}$

\section{$\mathrm{KMnO}_{4}$ footprinting}

A 5'-32P-labeled blunt-ended DNA (Figure 5) was made by annealing an unlabeled DNA strand $10(n=0)$ (Figure 1c) with a 5'-32 P-labeled DNA strand $\mathbf{9}(n=0)$ (Figure 1c) as described above. Strand 9 was labeled using T4 polynucleotide kinase (US Biochemical Corp., Cleveland, $\mathrm{OH}$ ) and $\gamma_{-}{ }^{32} \mathrm{P}-\mathrm{ATP}$ (Perkin Elmer, Wellesley, MA) followed by purification as described ${ }^{62} .2 \mathrm{nM}$ of this $5^{\prime}{ }^{32} \mathrm{P}$-labeled dsDNA was incubated with $1 \mu \mathrm{M}$ of RecBC in buffer $\mathrm{M}$ plus the indicated $\left[\mathrm{MgCl}_{2}\right]$ and $[\mathrm{NaCl}]$ over ice for $20 \mathrm{~min}$. Freshly prepared $\mathrm{KMnO}_{4}$ solution was added to the RecBC-DNA mixture to a final concentration of $2 \mathrm{mM}$. This reaction was allowed to proceed for $3 \mathrm{~min}$ at $25^{\circ} \mathrm{C}$ and was quenched by adding 2-ME to a final concentration of $2 \mathrm{M}$. A $5^{\prime}-{ }^{32} \mathrm{P}$-labeled ssDNA strand 9 with $n=15$ nucleotides was also added at this point to a final concentration of $2 \mathrm{nM}$ as a control. DNA was then extracted by phenol extraction as described 67 and followed by ethanol precipitation and piperidine digestion as described elsewhere ${ }^{68}$. The samples were run on a $20 \%$ polyarcrylamide gel with $7 \mathrm{M}$ urea at $55^{\circ} \mathrm{C}$ for one hour as described 68 and the gel was exposed to a phosphor screen and quantified with a Storm 840 system (Molecular Dynamics, Sunnyvale, CA).

\section{Acknowledgements}

We thank Drs. Roberto Galletto, Gerry Smith and Aaron Lucius and Colin Wu for stimulating discussions and comments on the manuscript and T. Ho for synthesis and purification of DNA. This research was supported in part by NIH grant GM45948 to T.M.L.

\section{Appendix}

The probability of a nucleotide within a duplex DNA is bound with only $\mathrm{Na}^{+}$and no $\mathrm{Mg}^{2+}$ when the duplex DNA is placed in a buffer containing both cations is calculated using equation $\mathrm{A}(1)$ as described $42 ; 43$.

$$
P_{\mathrm{Na}}=\frac{\left[\mathrm{D}_{0}\right]}{[\mathrm{D}]}=\frac{2}{1+\sqrt{1+4 K_{\mathrm{obs}}^{\mathrm{Mg}}\left[\mathrm{Mg}^{2+}\right]}}
$$

where $[D]$ is the total nucleotide concentration, $\left[\mathrm{D}_{0}\right]$ is the concentration of nucleotides associated with only $\mathrm{Na}^{+}$and $K_{\mathrm{obs}}^{\mathrm{Mg}}$ is the observed intrinsic constant for $\mathrm{Mg}^{2+}$ binding to each DNA site. As shown by equation $\mathrm{A}(1), P_{\mathrm{Na}}$ equals one before any addition of $\mathrm{Mg}^{2+}$ and it will decrease as $\left[\mathrm{Mg}^{2+}\right]$ increases, indicating an increasing probability of $\mathrm{Mg}^{2+}$ binding to the DNA. The dependence of $K_{\text {obs }}^{\mathrm{Mg}}$ on [ $\left.\mathrm{NaCl}\right]$ has been determined from the non-specific interactions 
between lac repressor and duplex DNA 42 as well as pentalysine and duplex DNA 43 and given in equations $\mathrm{A}(2)$ and $\mathrm{A}(3)$, respectively:

$$
\begin{gathered}
\log K_{\mathrm{obs}}^{\mathrm{Mg}}=-1.75 \log [\mathrm{NaCl}]+0.35 \\
\log K_{\mathrm{obs}}^{\mathrm{Mg}}=-(1.7 \pm 0.1) \log [\mathrm{NaCl}]+(0.3 \pm 0.2)
\end{gathered}
$$

In the presence of $100 \mathrm{mM} \mathrm{NaCl}$, using either equation $\mathrm{A}(2)$ or $\mathrm{A}(3)$, one obtains an estimate for $K_{\mathrm{obs}}^{\mathrm{Mg}} \approx 100 \quad \mathrm{M}^{-1}$. Thus in the presence of $10 \mathrm{mM} \mathrm{MgCl}_{2}$ and $100 \mathrm{mM} \mathrm{NaCl}$ one obtains a value of $P_{\mathrm{Na}} \approx 0.62$ using equation A(1). Similarly, in the presence of $400 \mathrm{mM} \mathrm{NaCl}$, $K_{\mathrm{obs}}^{\mathrm{Mg}} \approx 9.5 \quad \mathrm{M}^{-1}$ and $P_{\mathrm{Na}} \approx 0.95$ when $10 \mathrm{mM} \mathrm{MgCl}_{2}$ is present.

\section{References}

1. Matson SW, Bean DW, George JW. DNA helicases: enzymes with essential roles in all aspects of DNA metabolism. Bioessays 1994;16:13-22. [PubMed: 8141804]

2. Lohman TM, Bjornson KP. Mechanisms of Helicase-Catalyzed DNA Unwinding. Ann.Rev.Biochem 1996;65:169-214. [PubMed: 8811178]

3. Delagoutte E, von Hippel PH. Helicase mechanisms and the coupling of helicases within macromolecular machines. Part I: Structures and properties of isolated helicases. Q Rev Biophys 2002;35:431-78. [PubMed: 12621862]

4. Singleton MR, Dillingham MS, Wigley DB. Structure and Mechanism of Helicases and Nucleic Acid Translocases. Annu Rev Biochem 2007;76:23-50. [PubMed: 17506634]

5. Eggleston AK, O'Neill TO, Bradbury EM, Kowalczykowski SC. Unwinding of Nucleosomal DNA by a DNA Helicase. J.Biol.Chem 1995;270:2024-2031. [PubMed: 7836428]

6. Byrd AK, Raney KD. Displacement of a DNA binding protein by Dda helicase. Nucl. Acids Res 2006;34:3020-9. [PubMed: 16738140]

7. Veaute X, Jeusset J, Soustelle C, Kowalczykowski SC, Le Cam E, Fabre F. The Srs2 helicase prevents recombination by disrupting Rad51 nucleoprotein filaments. Nature 2003;423:309-12. [PubMed: 12748645]

8. Veaute X, Delmas S, Selva M, Jeusset J, Le Cam E, Matic I, Fabre F, Petit MA. UvrD helicase, unlike Rep helicase, dismantles RecA nucleoprotein filaments in Escherichia coli. EMBO J 2005;24:180-9. [PubMed: 15565170]

9. Kowalczykowski SC, Dixon DA, Eggleston AK, Lauder SD, Rehrauer WM. Biochemistry of homologous recombination in Escherichia coli. Microbiological Reviews 1994;58:401-465. [PubMed: 7968921]

10. Smith GR. Homologous recombination near and far from DNA breaks: alternative roles and contrasting views. Annu Rev Genet 2001;35:243-74. [PubMed: 11700284]

11. Gorbalenya AE, Koonin EV. Helicases: amino acid sequence comparisons and structure-function relationships. Curr.Op.Struct.Biol 1993;3:419-429.

12. Boehmer PE, Emmerson PT. The RecB subunit of the Escherichia coli RecBCD Enzyme Couples ATP Hydrolysis to DNA Unwinding. J.Biol.Chem 1992;267:4981-4987. [PubMed: 1311326]

13. Dillingham MS, Spies M, Kowalczykowski SC. RecBCD enzyme is a bipolar helicase. Nature 2003;423:893-897. [PubMed: 12815438]

14. Taylor AF, Smith GR. RecBCD enzyme is a DNA helicase with fast and slow motors of opposite polarity. Nature 2003;423:889-893. [PubMed: 12815437]

15. Smith GR, Kunes SM, Schultz DW, Taylor A, Triman KL. Structure of chi hotspots of generalized recombination. Cell 1981;24:429-36. [PubMed: 6453653]

16. Taylor AF, Schultz DW, Ponticelli AS, Smith GR. RecBC enzyme nicking at Chi sites during DNA unwinding: location and orientation-dependence of the cutting. Cell 1985;41:153-63. [PubMed: 3888405]

17. Ponticelli AS, Schultz DW, Taylor AF, Smith GR. Chi-dependent DNA strand cleavage by RecBC enzyme. Cell 1985;41:145-51. [PubMed: 3888404] 
18. Anderson DG, Kowalczykowski SC. The Translocating RecBCD Enzyme Stimulates Recombination by Directing RecA Protein onto ssDNA in a $\chi$-regulated Manner. Cell 1997;90:77-86. [PubMed: 9230304]

19. Chaudhury AM, Smith GR. A new class of Escherichia coli recBC mutants: implications for the role of RecBC enzyme in homologous recombination. Proc Natl Acad Sci U S A 1984;81:7850-4. [PubMed: 6393130]

20. Thaler DS, Stahl FW. DNA double-chain breaks in recombination of phage $\lambda$ and of yeast. Ann.Rev.Genet 1988;22:169-197. [PubMed: 2977087]

21. Chaudhury AM, Smith GR. Role of Escherichia coli RecBC enzyme in SOS induction. Mol Gen Genet 1985;201:525-8. [PubMed: 3911029]

22. Amundsen SK, Taylor AF, Chaudhury AM, Smith GR. recD: the gene for an essential third subunit of exonuclease V. Proc.Natl.Acad.Sci.USA 1986;83:5558-5562. [PubMed: 3526335]

23. Palas KM, Kushner SR. Biochemical and Physical Characterization of Exonuclease V from Escherichia coli. Comparson of the Catalytic Activities of the RecBC and RecBCD Enzymes. J.Biol.Chem 1990;265:3447-3454. [PubMed: 2154479]

24. Chen HW, Randle DE, Gabbidon M, Julin DA. Functions of the ATP hydrolysis subunits (RecB and RecD) in the nuclease reactions catalyzed by the RecBCD enzyme from Escherichia coli. J Mol Biol 1998;278:89-104. [PubMed: 9571036]

25. Yu M, Souaya J, Julin DA. Identification of the Nuclease Active Site in the Multifunctional RecBCD Enzyme by Creation of a Chimeric Enzyme. J.Mol.Biol 1998;283:797-808. [PubMed: 9790841]

26. Yu M, Souaya J, Julin DA. The 30-kDa C-terminal domain of the RecB protein is critical for the nuclease activity, but not the helicase activity, of the RecBCD enzyme from Escherichia coli. Proc.Natl.Acad.Sci.,U.S.A 1998;95:981-986. [PubMed: 9448271]

27. Singleton MR, Dillingham MS, Gaudier M, Kowalczykowski SC, Wigley DB. Crystal structure of RecBCD enzyme reveals a machine for processing DNA breaks. Nature 2004;432:187-93. [PubMed: 15538360]

28. Taylor AF, Smith GR. Substrate specificity of the DNA unwinding activity of the recBC enzyme of Escherichia coli. J.Mol.Biol 1985;185:431-443. [PubMed: 2997450]

29. Roman LJ, Kowalczykowski SC. Characterization of the helicase activity of the Escherichia coli RecBCD enzyme using a novel helicase assay. Biochemistry 1989;28:2863-2873. [PubMed: 2545238]

30. Korangy F, Julin DA. Kinetics and Processivity of ATP Hydrolysis and DNA Unwinding by the RecBC Enzyme from Escherichia coli. Biochemistry 1993;32:4873-4880. [PubMed: 8387820]

31. Lucius AL, Vindigni A, Gregorian R, Ali JA, Taylor AF, Smith GR, Lohman TM. DNA Unwinding Step-size of E. coli RecBCD Helicase Determined from Single Turnover Chemical Quenched-flow Kinetic Studies. J. Mol. Biol 2002;324:409-428. [PubMed: 12445778]

32. Lucius AL, Jason Wong C, Lohman TM. Fluorescence stopped-flow studies of single turnover kinetics of E.coli RecBCD helicase-catalyzed DNA unwinding. J. Mol. Biol 2004;339:731-50. [PubMed: 15165847]

33. Lucius AL, Lohman TM. Effects of temperature and ATP on the kinetic mechanism and kinetic stepsize for E.coli RecBCD helicase-catalyzed DNA unwinding. J. Mol. Biol 2004;339:751-71. [PubMed: 15165848]

34. Ganesan S, Smith GR. Strand-specific binding to duplex DNA ends by the subunits of the Escherichia coli RecBCD enzyme. J.Mol.Biol 1993;229:67-78. [PubMed: 8380618]

35. Farah JA, Smith GR. The RecBCD Enzyme Initiation Complex for DNA Unwinding: Enzyme Positioning and DNA Opening. J.Mol.Biol 1997;272:699-715. [PubMed: 9368652]

36. Taylor AF, Smith GR. Strand Specificity of Nicking of DNA at Chi Sites by RecBCD Enzyme. J.Biol.Chem 1995;270:24459-24467. [PubMed: 7592661]

37. Wong CJ, Lucius AL, Lohman TM. Energetics of DNA end binding by E.coli RecBC and RecBCD helicases indicate loop formation in the 3'-single-stranded DNA tail. J. Mol. Biol 2005;352:765-82. [PubMed: 16126227]

38. Anderson CF, Record J,MT. Salt-Nucleic Acid Interactions. Annu.Rev.Phys.Chem 1995;46:657700. [PubMed: 7495482] 
39. Record MT Jr. Lohman ML, De Haseth P. Ion effects on ligand-nucleic acid interactions. J Mol Biol 1976;107:145-58. [PubMed: 1003464]

40. Record MT, Anderson CF, Lohman TM. Thermodynamic analysis of ion effects on the binding and conformational equilibria of proteins and nucleic acids: the roles of ion association or release, screening, and ion effects on water activity. Quart.Rev.Biophys 1978;11:103-178.

41. Lohman TM, Mascotti DP. Thermodynamics of ligand-nucleic acid interactions. Methods Enzymol 1992;212:400-24. [PubMed: 1518457]

42. Record MT Jr. deHaseth PL, Lohman TM. Interpretation of monovalent and divalent cation effects on the lac repressor-operator interaction. Biochemistry 1977;16:4791-6. [PubMed: 911790]

43. Lohman TM, de Haseth PL, Record MT. Pentalysine-deoxyribonucleic acid interactions: a model for the general effects of ion concentrations on the interactions of proteins with nucleic acids. Biochem 1980;19:3522-3530. [PubMed: 7407056]

44. Overman LB, Bujalowski W, Lohman TM. Equilibrium binding of Escherichia coli single-strand binding protein to single-stranded nucleic acids in the (SSB) 65 binding mode. Cation and anion effects and polynucleotide specificity. Biochemistry 1988;27:456-71. [PubMed: 3280021]

45. Lohman TM, Mascotti DP. Nonspecific ligand-DNA equilibrium binding parameters determined by fluorescence methods. Methods Enzymol 1992;212:424-58. [PubMed: 1518458]

46. Hayatsu H, Ukita T. The selective degradation of pyrimidines in nucleic acids by permanganate oxidation. Biochem Biophys Res Commun 1967;29:556-61. [PubMed: 16496535]

47. Nayal M, Di Cera E. Predicting Ca2+-binding sites in proteins. Proc. Natl. Acad. Sci. U.S.A 1994;91:817-821. [PubMed: 8290605]

48. Yamashita MM, Wesson L, Eisenman G, Eisenberg D. Where metal ions bind in proteins. Proc Natl Acad Sci U S A 1990;87:5648-52. [PubMed: 2377604]

49. Rosamond J, Telander KM, Linn S. Modulation of the action of the recBC enzyme of Escherichia coli K-12 by Ca2+. J Biol Chem 1979;254:8646-52. [PubMed: 157358]

50. Rigden DJ. An inactivated nuclease-like domain in $\mathrm{RecC}$ with novel function: implications for evolution. BMC Struct Biol 2005;5:9. [PubMed: 15985153]

51. Holbrook JA, Capp MW, Saecker RM, Record MT Jr. Enthalpy and heat capacity changes for formation of an oligomeric DNA duplex: interpretation in terms of coupled processes of formation and association of single-stranded helices. Biochemistry 1999;38:8409-22. [PubMed: 10387087]

52. Sturtevant JM. Heat capacity and entropy changes in processes involving proteins. Proc Natl Acad Sci U S A 1977;74:2236-40. [PubMed: 196283]

53. Spolar RS, Record MT. Coupling of local folding to site-specific binding of proteins to DNA. Science 1994;263:777-784. [PubMed: 8303294]

54. Kozlov AG, Lohman TM. Adenine base unstacking dominates the observed enthalpy and heat capacity changes for the Escherichia coli SSB tetramer binding to single-stranded oligoadenylates. Biochemistry 1999;38:7388-7397. [PubMed: 10353851]

55. Kozlov AG, Lohman TM. Large Contributions of Coupled Protonation Equilibria to the Observed Enthalpy and Heat Capacity Changes for ssDNA Binding to Escherichia coli SSB Protein.

PROTEINS: Structure, Function, and Genetics 2000;(Suppl 4):8-22.

56. Kozlov AG, Lohman TM. Effects of monovalent anions on a temperature-dependent heat capacity change for Escherichia coli SSB tetramer binding to single-stranded DNA. Biochemistry 2006;45:5190-205. [PubMed: 16618108]

57. Ladbury JE, Wright JG, Sturtevant JM, Sigler PB. A thermodynamic study of the trp repressoroperator interaction. J.Mol.Biol 1994;238:669-681. [PubMed: 8182742]

58. Vesnaver G, Breslauer KJ. The contribution of DNA single-stranded order to the thermodynamics of duplex formation. Proc Natl Acad Sci U S A 1991;88:3569-73. [PubMed: 2023903]

59. SantaLucia J,J. A unified view of polymer, dumbbell, and oligonucleotide DNA nearest-neighbor thermodynamics. Proc.Natl.Acad.Sci.,U.S.A 1998;95:1460-1465. [PubMed: 9465037]

60. Wolf, AV.; Brown, MG.; Prentiss, PG. Concentrative properties of aqueous solutions: conversion tables.. In: Weast, RC., editor. CRC Handbook of Chemical and Physical Data. 55 edit.. CRC Press; Cleveland: 1974. 
61. Wong CJ, Rice RL, Baker NA, Ju T, Lohman TM. Probing 3'-ssDNA Loop Formation in E. coli RecBCD/RecBC-DNA Complexes Using Non-natural DNA: A Model for "Chi”" Recognition Complexes. J. Mol. Biol 2006;362:26-43. [PubMed: 16901504]

62. Wong I, Chao KL, Bujalowski W, Lohman TM. DNA-induced dimerization of the Escherichia coli rep helicase. Allosteric effects of single-stranded and duplex DNA. J Biol Chem 1992;267:7596610. [PubMed: 1313807]

63. Gray DM, Hung SH, Johnson KH. Absorption and Circular Dichroism Spectroscopy of Nucleic Acid Duplexes and Triplexes. Methods in Enzymology 1995;246:19-34. [PubMed: 7538624]

64. Mascotti, DP. Ph.D. thesis. Texas A\&M University; 1992. Charged oligopeptide-nucleic acid interactions as models of the electrostatic component of protein-nucleic acid interactions.

65. Jezewska MJ, Bujalowski W. A General Method of Analysis of Ligand Binding to Competing Macromolecules Using the Spectroscopic Signal Originating from a Reference Macromolecule. Application to Escherichia coli Replicative Helicase DnaB Protein-Nucleic Acid Interactions. Biochemistry 1996;35:2117-2128. [PubMed: 8652554]

66. Kozlov AG, Lohman TM. Calorimetric studies of E-coli SSB protein single-stranded DNA interactions. Effects of monovalent salts on binding enthalpy. Journal of Molecular Biology 1998;278:999-1014. [PubMed: 9600857]

67. Maniatis, T.; Fritsch, EF.; Sambrook, J. Molecular Cloning: A Laboratory Manual. Cold Spring Harbor Laboratory Press; Cold Spring Harbor, NY: 1982.

68. Ausubel, FM.; Brent, R.; Kingston, RE.; Moore, DD.; Seidman, JG.; Smith, JA.; Struhl, K. Current Protocols in Molecular Biology. John Wiley and Sons, Inc.; 1987. 


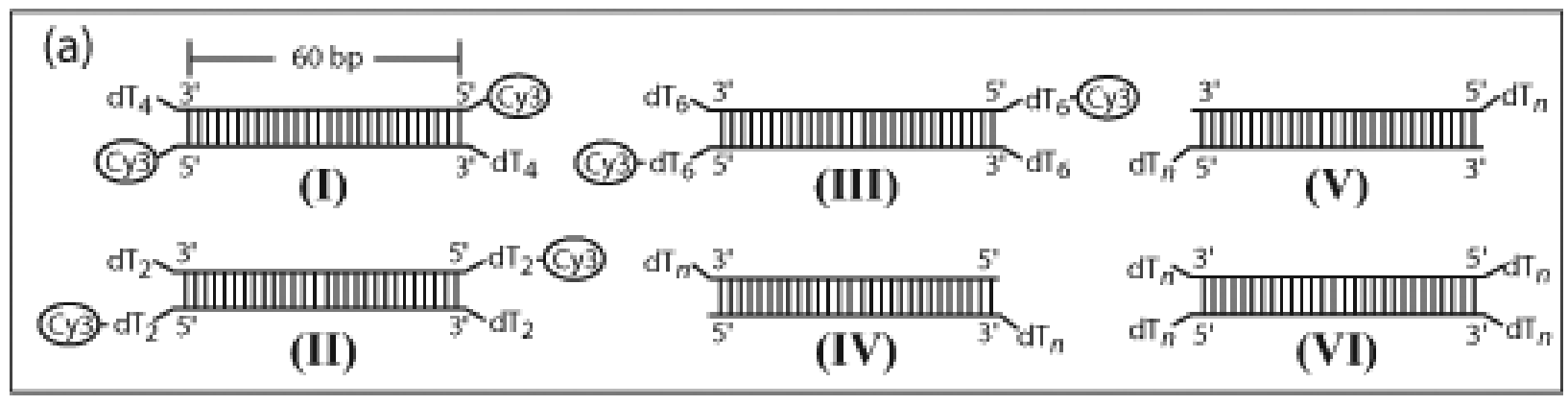

(b)

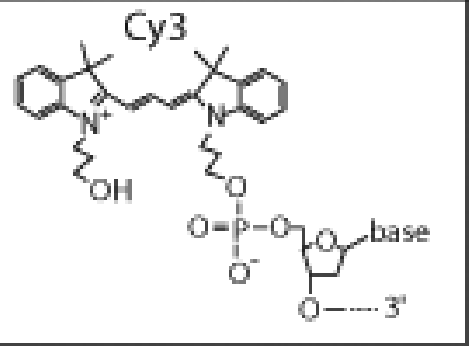

(c)

\begin{tabular}{ll}
\hline & Sequences of Fluorescently Labeled Single Stranded DNA used to form Reference DNA I through III \\
\hline $\mathbf{1}$ & 5'-(Cy3)CCATGGCTCCTGAGCTAGCTGCAGTAGCCTAAAGGATGAAACTAGGATCTTATGCTCCAGTITT-3' \\
$\mathbf{2}$ & 5'-(Cy3)CTGGAGCATAAGATCCTAGTTCATCCTTTAGGCTACTGCAGCTAGCTCAGGAGCCATGGTTT-3' \\
$\mathbf{3}$ & 5'-(Cy3)TTCCATGGCTCCTGAGCTAGCTGCAGTAGCCTAAAGGATGAAACTAGGATCTTATGCTCCAGTT-3' \\
$\mathbf{4}$ & 5'-(Cy3)TTCTGGAGCATAAGATCCTAGTTTCATCCTTTAGGCTACTGCAGCTAGCTCAGGAGCCATGGTT-3' \\
$\mathbf{5}$ & 5'-(Cy3)TTTTTCCATGGCTCCTGAGCTAGCTGCAGTAGCCTAAAGGATGAAACTAGGATCTTATGCTCCAGTIITT-3' \\
$\mathbf{6}$ & 5'-(Cy3)TTTTTTCTGGAGCATAAGATCCTAGTTCATCCTTTAGGCTACTGCAGCTAGCTCAGGAGCCATGGTTTTT-3' \\
\hline
\end{tabular}

\begin{tabular}{|c|c|}
\hline & Sequences of Unlabeled Single Stranded DNA used to form Competitor DNA IV through VI \\
\hline 7 & 5'-CCATGGCTCCTGAGCTAGCTGCAGTAGCCTAAAGGATGAAACTAGGATCTTATGCTCCAG(T) ${ }_{n}-3^{\prime}$ \\
\hline 8 & S'-CTGGAGCATAAGATCCTAGTTTCATCCTTTAGGCTACTGCAGCTAGCTCAGGAGCCATGG $(T)_{n}=3^{\prime}$ \\
\hline 9 & 5'-(T), CCATGGCTCCTGAGCTAGCTGCAGTAGCCTAAAGGATGAAACTAGGATCTTATGCTCCAG-3' \\
\hline 10 & $5^{\prime}-(T)_{n} C T G G A G C A T A A G A T C C T A G T T T C A T C C T T T A G G C T A C T G C A G C T A G C T C A G G A G C C A T G G-3^{\prime}$ \\
\hline 11 & $S^{\prime}$-(T) ${ }_{n}$ CCATGGCTCCTGAGCTAGCTGCAGTAGCCTAAAGGATGAAACTAGGATCTTATGCTCCAG(T) ${ }_{n}-3^{\prime}$ \\
\hline 12 & $5^{\prime}-(T)_{n}$ CTGGAGCATAAGATCCTAGTTTCATCCTTTAGGCTACTGCAGCTAGCTCAGGAGCCATGG $(T)_{n}{ }^{-3} 3^{\prime}$ \\
\hline
\end{tabular}

Figure 1.

DNA molecules used for RecBC equilibrium binding studies. (a) Schematic representations of Cy3-labeled reference DNA molecules I through III and the non-fluorescent competitor series DNA IV to VI. (b) Structure of the Cy3 fluorophore and its covalent attachment to the phosphate group on the 5'-end of the DNA via a three-carbon linker. (c) Sequences of all DNA strands used to form DNA molecules shown in (a). Reference DNA I was formed from strands $\mathbf{1}$ and 2; reference DNA II was formed from strands $\mathbf{3}$ and $\mathbf{4}$; reference DNA III was formed from strands $\mathbf{5}$ and $\mathbf{6}$; DNA series IV was formed from strands $\mathbf{7}$ and $\mathbf{8}$; DNA series $\mathbf{V}$ was formed from strands $\mathbf{9}$ and 10; and DNA series VI was formed from strands $\mathbf{1 1}$ and $\mathbf{1 2}$. 
[NaCl] (M)

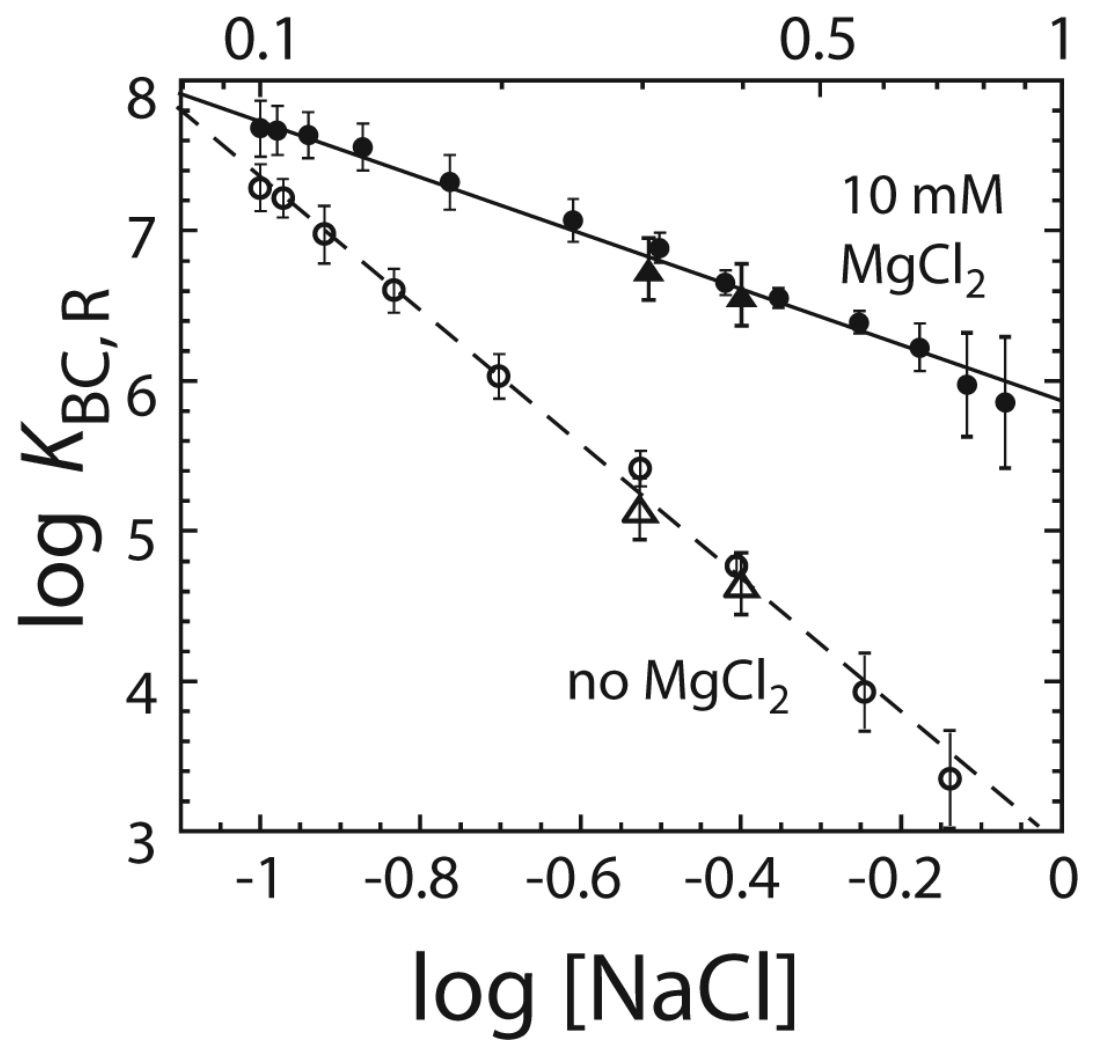

Figure 2.

Effects of $\mathrm{Mg}^{2+}$ on the $\left[\mathrm{Na}^{+}\right]$-dependence of the equilibrium constant $\left(K_{\mathrm{BC}, \mathrm{R}}\right)$ for $\mathrm{RecBC}$ binding to an end of reference DNA I. Values of $\log K_{\mathrm{BC}, \mathrm{R}}$ for reference DNA I are plotted as a function of $\log \left[\mathrm{Na}^{+}\right]$. The data were obtained from "salt-back titrations" as described in Materials and Methods in buffer $\mathrm{M}$ at $25^{\circ} \mathrm{C}$ in the presence of $10 \mathrm{mM} \mathrm{MgCl}_{2}(\bullet)$ or in the absence of $\mathrm{MgCl}_{2}(\mathrm{O})$. Data were also obtained from direct measurement of $K_{\mathrm{BC}, \mathrm{R}}$ in buffer $\mathrm{M}$ plus the indicated $[\mathrm{NaCl}]$ in the presence of $10 \mathrm{mM} \mathrm{MgCl}_{2}(\boldsymbol{\Delta})$ or in the absence of $\mathrm{MgCl}_{2}(\Delta)$. The solid and short dash lines are linear fits to the data obtained in buffer $\mathrm{M}$ with or without $10 \mathrm{mM} \mathrm{MgCl}_{2}$, respectively. The slopes obtained from the linear fits are $-1.9 \pm 0.4$ in the presence of $10 \mathrm{mM} \mathrm{MgCl} 2$ and $-4.5 \pm 0.6$ in the absence of $\mathrm{MgCl}_{2}$. 

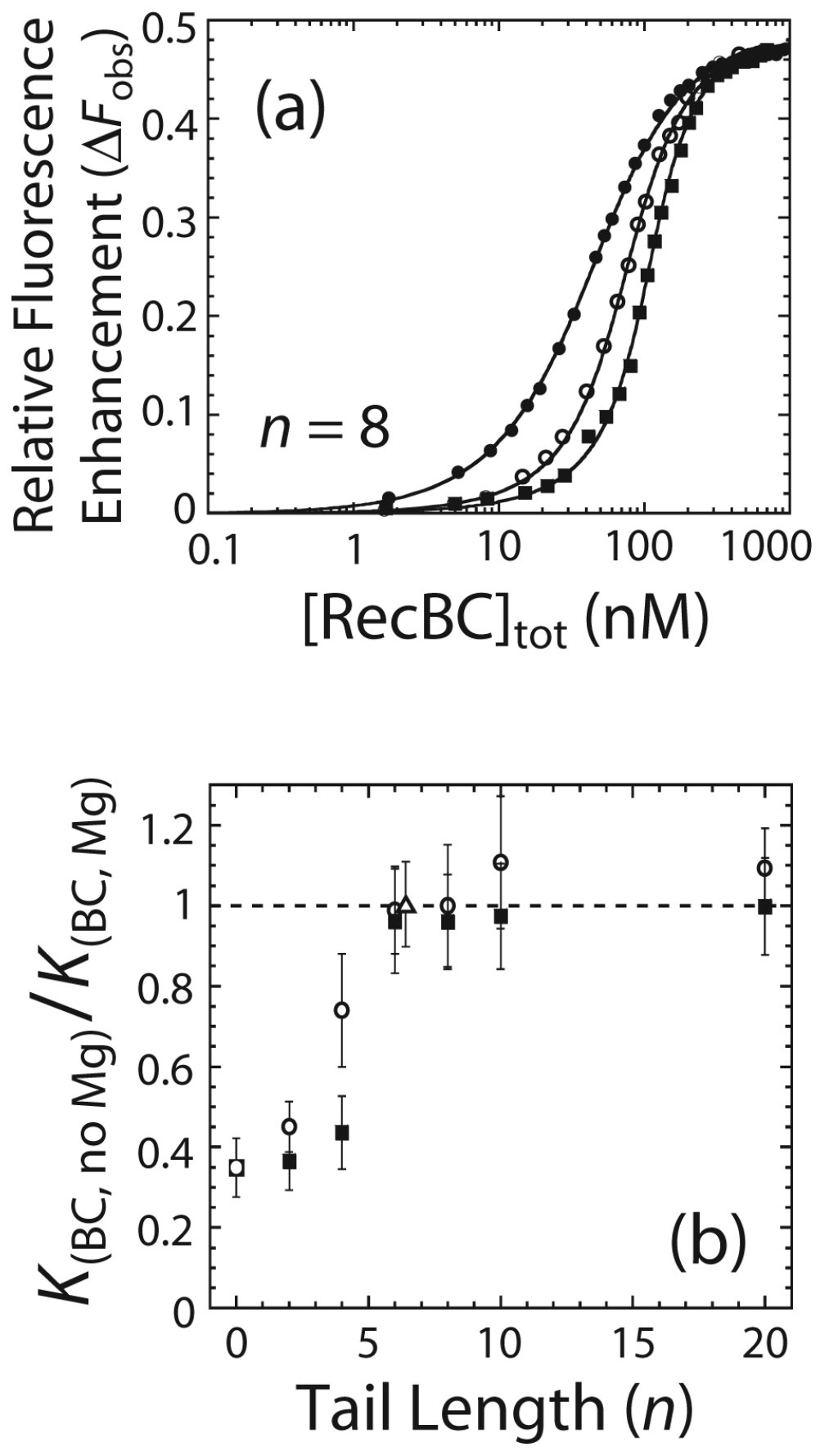

Figure 3.

Effects of $\mathrm{Mg}^{2+}$ on the equilibrium constants $\left(K_{\mathrm{BC}}\right)$ for RecBC binding to DNA ends containing pre-formed ss-(dT) $)_{n}$ tails. (a) Representative equilibrium competition titrations to determine $K_{\mathrm{BC}}$ for binding to the ends of a non-fluorescent DNA IV series molecule containing 3'$(\mathrm{dT})_{8}$ tails. Mixtures of Cy3 labeled reference DNA I $(20 \mathrm{nM})$ and the non-fluorescent DNA IV molecule was titrated with RecBC in buffer $\mathrm{M}, 10 \mathrm{mM} \mathrm{MgCl}_{2}$ plus $100 \mathrm{mM} \mathrm{NaCl}$ at $25^{\circ}$ $\mathrm{C}$ and the relative $\mathrm{Cy} 3$ fluorescence enhancement $\left(\Delta F_{\text {obs }}\right)$ is plotted as a function of total $[\mathrm{RecBC}]$. Three separate titration experiments were performed in which a constant total reference DNA I concentration was used for all experiments but the total concentrations of the competitor DNA IV substrates were varied in each titration. $(\bullet)$ represents a titration performed 
in the presence of only reference DNA I $(20 \mathrm{nM})$, while ( 0 ) and (- represent experiments performed in the presence DNA I $(20 \mathrm{nM})$ and 20 or $40 \mathrm{nM}$ DNA IV with 3'-(dT) $)_{8}$, respectively. Solid lines are simulations using the best fit values of $K_{\mathrm{BC}}$ (Table 1) as described previously 37 . (b) Ratios of $K_{\mathrm{BC}}$ measured in the absence of $\mathrm{Mg}^{2+}$ (Table 1) to $K_{\mathrm{BC}}$ measured in $10 \mathrm{mM} \mathrm{MgCl} 2$ (Table 1) are plotted as a function of the length of pre-existing ss-(dT) $)_{n}$ tail (n). (०) represents ratios of $K_{\mathrm{BC}}$ for the DNA IV series with pre-existing 3'-(dT) $)_{n}$ tails; (ש) represents ratios of $K_{\mathrm{BC}}$ for the DNA $\mathbf{V}$ series with pre-existing 5'-(dT) $)_{n}$ tails; and ( $\triangle$ ) represents ratio of $K_{\mathrm{BC}}$ for a DNA VI molecule with pre-existing twin- $(\mathrm{dT})_{6}$ tails. 

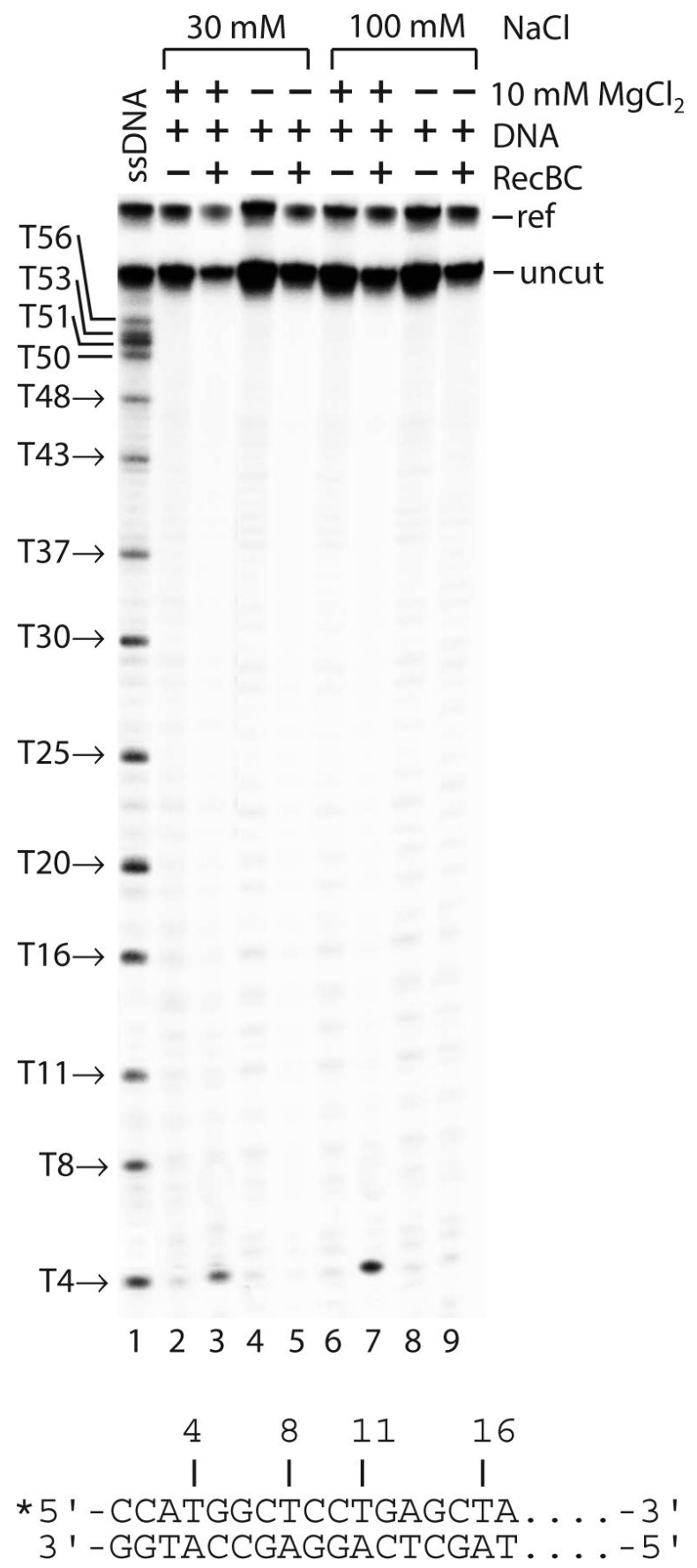

Figure 4.

Effects of $\mathrm{Mg}^{2+}$ on the chemical protection patterns of a blunt-ended DNA bound by RecBC. $\mathrm{KMnO}_{4}$ footprinting experiments of the RecBC-blunt-ended-DNA complex were performed in buffer $\mathrm{M}$ plus the indicated $[\mathrm{NaCl}]$ and $\left[\mathrm{MgCl}_{2}\right]$ at $25^{\circ} \mathrm{C}$ as described in Materials and Methods. Lane 1 is a control with just the $5{ }^{-32} \mathrm{P}$-labeled ssDNA top strand alone. The contents of lanes 2 through 9 are indicated in the figure. The asterisk in the inset shows the position of the ${ }^{32} \mathrm{P}$-label on the DNA. The reference DNA band is indicated by ref and the uncut sample DNA band is denoted by uncut. 

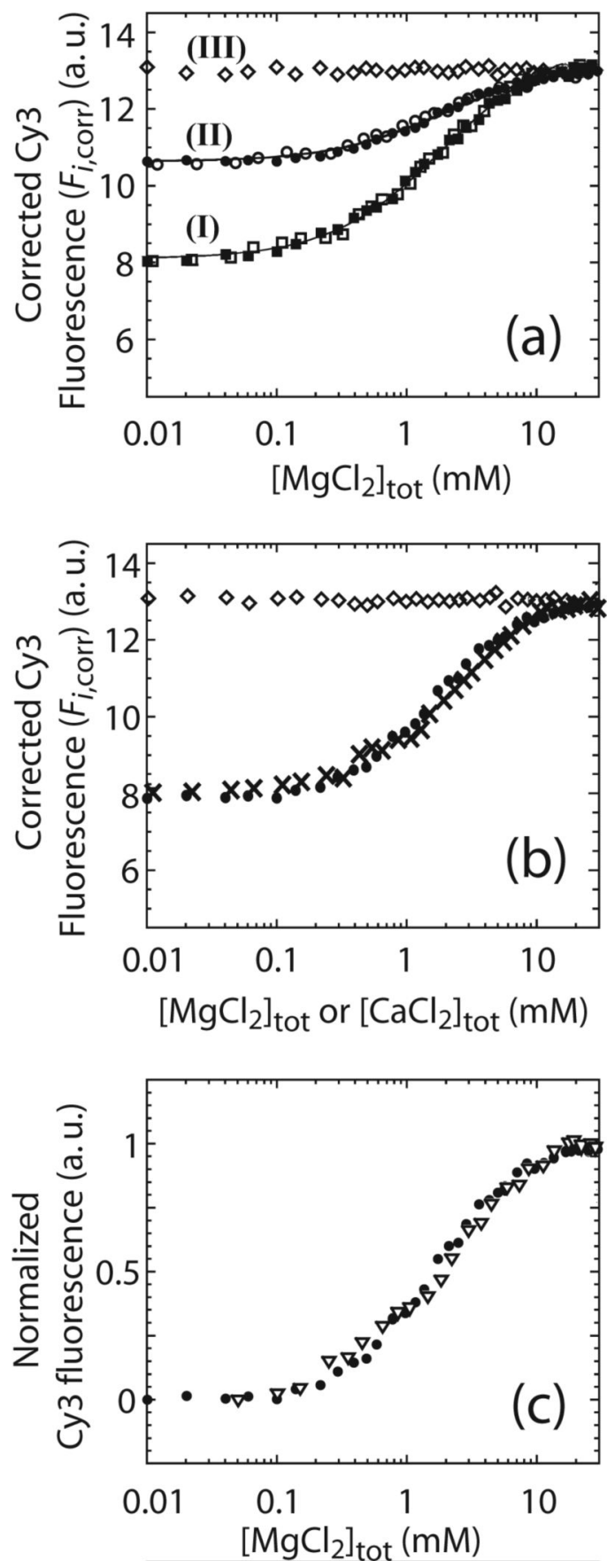

Figure 5.

Effects of $\mathrm{Mg}^{2+}$ on the Cy3 fluorescence signal of a RecBC-reference DNA complex. (a) 10 nM of DNA I ( $\bullet)$, DNA II $(\bullet)$ or DNA III $(\diamond)$ was pre-bound with $2.4,2.2$ or $1.3 \mu \mathrm{M} \mathrm{RecBC}$, respectively, and titrated with $\mathrm{MgCl}_{2}$ in buffer $\mathrm{M}$ plus $100 \mathrm{mM} \mathrm{NaCl}$ at $25^{\circ} \mathrm{C}$ and the corrected Cy3 fluorescence $\left(F_{i, \text { corr }}\right)$ was plotted as a function of total $\left[\mathrm{MgCl}_{2}\right]$. The same experiments were performed in buffer M plus $400 \mathrm{mM} \mathrm{NaCl}$ for DNA I ( $\square$ ) and DNA II (०). Solid lines are simulations using equations (13) to (15) and the best fit values of $K_{\mathrm{Mg}}^{\mathrm{BD}}$ and $K_{\mathrm{Mg}}^{\mathrm{B}}$ $\left((5 \pm 2) \times 10^{2} \mathrm{M}^{-1}\right.$, and $(8 \pm 3) \mathrm{M}^{-1}$ respectively). (b) Comparisons of $10 \mathrm{nM}$ of DNA I prebound with $2.4 \mu \mathrm{M}$ RecBC titrated with $\mathrm{MgCl}_{2}(\bullet)$ or $\mathrm{CaCl}_{2}(\times)$ in buffer M plus $100 \mathrm{mM}$ 
$\mathrm{NaCl}$ at $25^{\circ} \mathrm{C} . F_{i, \text { corr }}$ is plotted as a function of total $\left[\mathrm{MgCl}_{2}\right]$ or $\left[\mathrm{CaCl}_{2}\right] .10 \mathrm{nM}$ of DNA III pre-bound with $1.3 \mu \mathrm{M}$ RecBC was also titrated with $\mathrm{CaCl}_{2}(\diamond)$ in buffer M plus $100 \mathrm{mM}$ $\mathrm{NaCl}$ at $25^{\circ} \mathrm{C}$. (c) Comparisons of $10 \mathrm{nM}$ of DNA I pre-bound with either $2.4 \mu \mathrm{M} \mathrm{RecBC}(\bullet)$ or $2.4 \mu \mathrm{M} \mathrm{RecB}{ }^{\Delta \text { nuc }} \mathrm{C}(\nabla)$ and titrated with $\mathrm{MgCl}_{2}$ in buffer M plus $100 \mathrm{mM} \mathrm{NaCl}$ at $25^{\circ} \mathrm{C}$. $F_{i, \text { corr }}$ from each experiment was normalized arbitrarily to one and plotted as a function of $\left[\mathrm{MgCl}_{2}\right]$. 

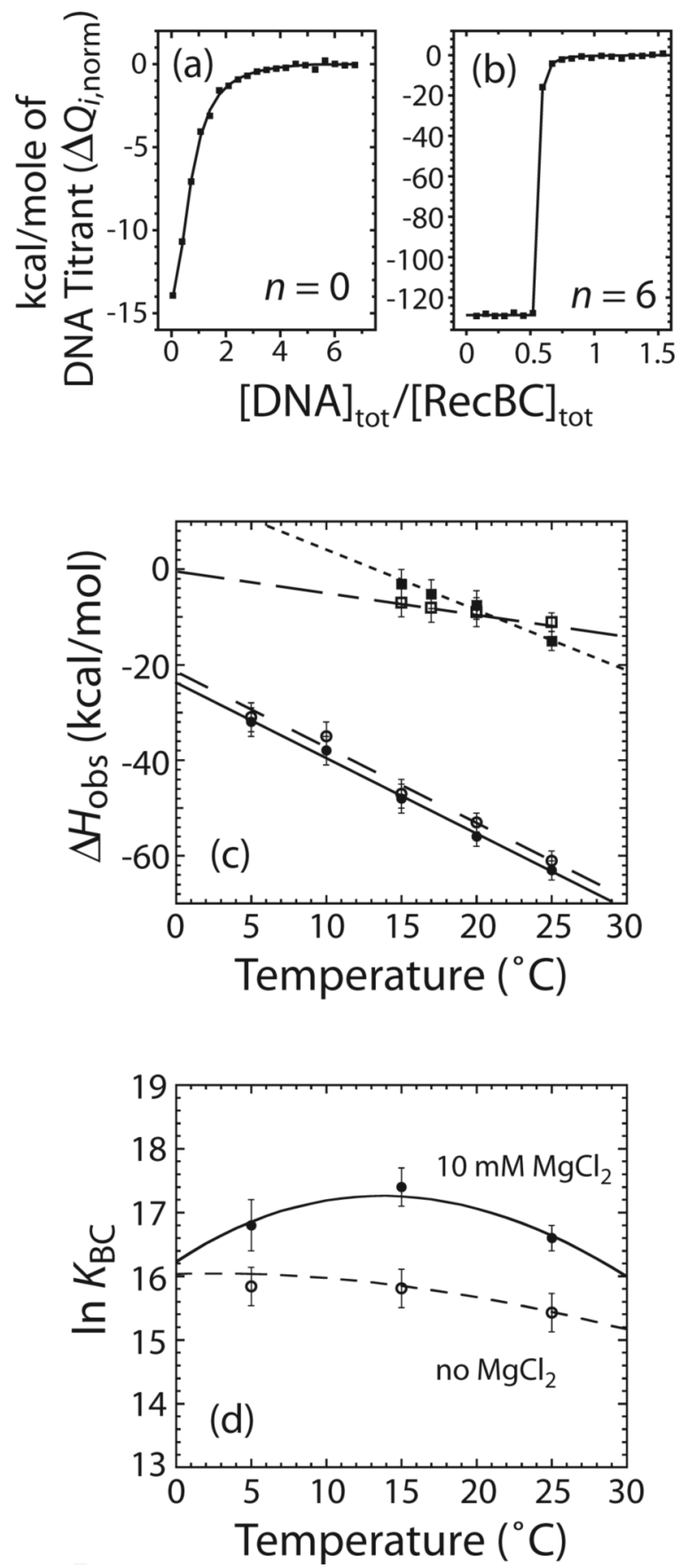

Figure 6.

Effects of $\mathrm{Mg}^{2+}$ on the temperature dependence of the observed enthalpic change $\left(\Delta H_{\mathrm{obs}}\right)$ for RecBC binding to one end of the DNA VI series molecules with $n=0$ or 6 . Experiments were performed in buffer $\mathrm{M}$ plus $100 \mathrm{mM} \mathrm{NaCl}$ and the indicated $\left[\mathrm{MgCl}_{2}\right]$ at the indicated temperature. (a) and (b) are representative ITC experiments to determine the enthalpic change for RecBC binding the ends of DNA VI series molecules with $n=0$ or 6 in the presence of 10 $\mathrm{mM} \mathrm{MgCl} 2$ at $25^{\circ} \mathrm{C}$. The heat of each injection normalized to the amount of DNA injected ( $\Delta Q_{i, \text { norm }}$ as defined in equation (20)) is plotted as a function of total [DNA]/total [RecBC]. (a) $710 \mathrm{nM}$ RecBC was titrated with $15.2 \mu \mathrm{M}$ DNA VI with $n=0$; (b) $885 \mathrm{nM}$ RecBC was titrated with $9 \mu \mathrm{M}$ DNA VI with $n=6$. Solid lines are simulations using equations (18) to (20) 
and the best fit values of $\Delta H_{\text {obs }}$ (Table 2) and $K_{\mathrm{BC}}=(1.6 \pm 0.3) \times 10^{7} \mathrm{M}^{-1}$ in (a) while $K_{\mathrm{BC}}$ $\geq 10^{9} \mathrm{M}^{-1}$ in (b). (c) Effects of $\mathrm{Mg}^{2+}$ on values of $\Delta C_{\mathrm{p} \text {,obs }}$ for RecBC binding to a DNA end. $\Delta H_{\mathrm{obs}}$ for RecBC binding to an end of DNA VI with $n=6$ in the presence of $10 \mathrm{mM} \mathrm{MgCl}$ $(\bullet)$ or in the absence of $\mathrm{MgCl}_{2}(\circ)$ and $\Delta H_{\text {obs }}$ for RecBC binding to a blunt DNA end in the presence of $10 \mathrm{mM} \mathrm{MgCl}$ ( $(\mathbf{})$ or in the absence of $\mathrm{MgCl}_{2}(\square)$ are plotted as a function of temperature $\left({ }^{\circ} \mathrm{C}\right)$. Straight lines represent results obtained from linear least-square analysis of each set of data and the value of $\Delta C_{\mathrm{p}, \text { obs }}$ obtained from each set of data is presented in Table 2. (d) Effects of $\mathrm{Mg}^{2+}$ on the temperature dependence of equilibrium constant $\left(K_{\mathrm{BC}}\right)$ for $\operatorname{RecBC}$ binding to a blunt DNA end measured by competition fluorescence titration experiments.

Experiments were performed in buffer $\mathrm{M}, 100 \mathrm{mM} \mathrm{NaCl}$ with or without $10 \mathrm{mM} \mathrm{MgCl}_{2}$ at the indicated temperature. Values of $\ln K_{\mathrm{BC}}$ measured in $10 \mathrm{mM} \mathrm{MgCl}_{2}(\bullet)$ or $0 \mathrm{mM} \mathrm{MgCl}_{2}$ (०) are plotted as a function of temperature $\left({ }^{\circ} \mathrm{C}\right)$. The solid and broken lines are simulations using equation (22) and the $\Delta H_{\mathrm{obs}}$ and $\Delta C_{\mathrm{p} \text {,obs }}$ values obtained from ITC experiments in the presence or absence of $10 \mathrm{mM} \mathrm{MgCl}_{2}$, respectively (Table 2). 


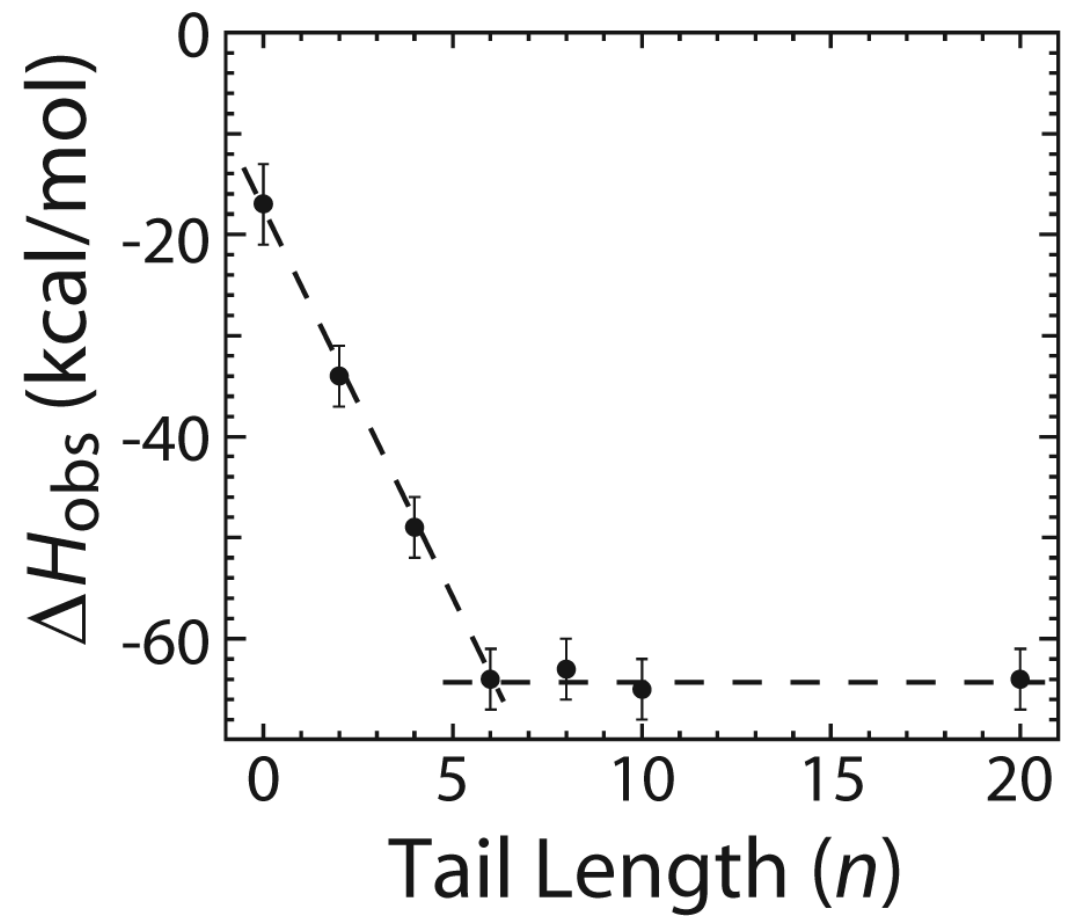

Figure 7.

Enthalpic cost of base pair melting by RecBC upon binding to a duplex DNA end. The observed enthalpic change $\left(\Delta H_{\mathrm{obs}}\right.$ ) for RecBC binding to one end of the DNA VI series containing twin ss- $(\mathrm{dT})_{n}$ tails with $n$ varying from zero to 20 nucleotides were measured in buffer M plus 10 $\mathrm{mM} \mathrm{MgCl} 2$ and $100 \mathrm{mM} \mathrm{NaCl}$ at $25^{\circ} \mathrm{C} . \Delta H_{\text {obs }}$ for RecBC binding to one end of the DNA DNA VI series $(\bullet)$ are plotted as a function of pre-existing ss- $(\mathrm{dT})_{n}$ tail length $(n)$. 


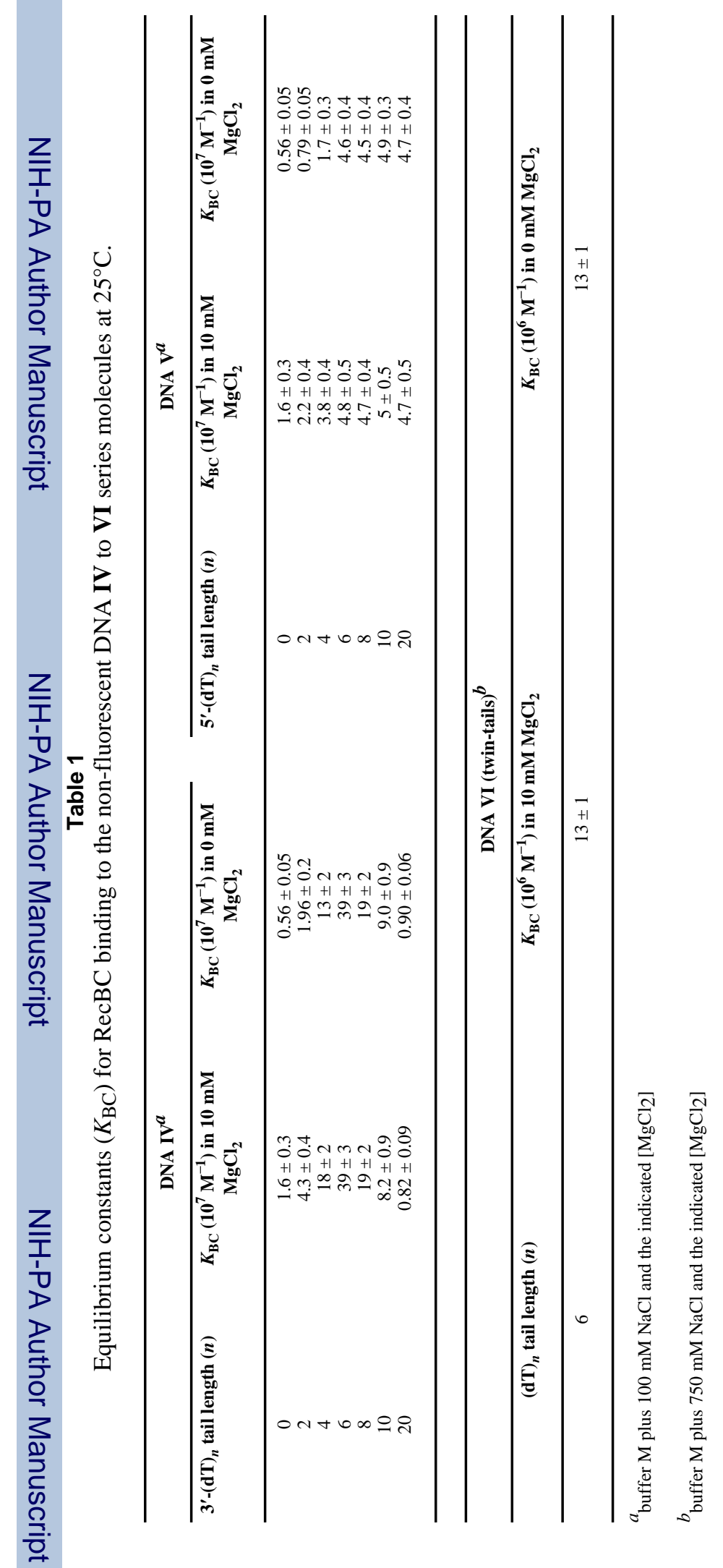

J Mol Biol. Author manuscript; available in PMC 2008 December 11. 


\section{Table 2}

Temperature dependence of the observed enthalpic change $\left(\Delta H_{\mathrm{obs}}\right)$ for RecBC binding to one end of the DNA VI series molecules with $n=0$ or 6 . Observed heat capacity change $\left(\Delta C_{\mathrm{p}, \mathrm{obs}}\right)$ values are obtained from linear least-square analyses of the observed enthalpic change data. (buffer $\mathrm{M}$ plus $100 \mathrm{mM} \mathrm{NaCl}$ and the indicated $\left[\mathrm{MgCl}_{2}\right]$ )

\begin{tabular}{|c|c|c|c|c|}
\hline \multirow[t]{2}{*}{ Temperature $\left({ }^{\circ} \mathbf{C}\right)$} & \multicolumn{2}{|c|}{ DNA with twin $(\mathrm{dT})_{6}$ tails } & \multicolumn{2}{|c|}{ Blunt-ended DNA } \\
\hline & 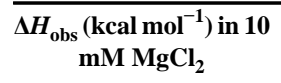 & $\begin{array}{c}\Delta H_{\mathrm{obs}}\left(\mathrm{kcal} \mathrm{mol}^{-1}\right) \text { in } 0 \\
\mathrm{mM} \mathrm{MgCl}\end{array}$ & $\begin{array}{c}\Delta H_{\mathrm{obs}}\left(\mathrm{kcal} \mathrm{mol}^{-1}\right) \text { in } \\
10 \mathrm{mM} \mathrm{MgCl}\end{array}$ & $\begin{array}{c}\Delta H_{\text {obs }}\left(\mathrm{kcal} \mathrm{mol}^{-1}\right) \text { in } \\
0 \mathrm{mM} \mathrm{MgCl}\end{array}$ \\
\hline $\begin{array}{c}5 \\
10 \\
15 \\
17 \\
20 \\
25\end{array}$ & $\begin{array}{c}-32 \pm 3 \\
-38 \pm 3 \\
-48 \pm 3 \\
\text { ND } \\
-56 \pm 3 \\
-64 \pm 3\end{array}$ & $\begin{array}{c}-31 \pm 3 \\
-35 \pm 3 \\
-47 \pm 3 \\
\mathrm{ND} \\
-53 \pm 2 \\
-61 \pm 2\end{array}$ & $\begin{array}{c}\text { ND } \\
\text { ND } \\
-3 \pm 3 \\
-5 \pm 3 \\
-8 \pm 3 \\
-15 \pm 2\end{array}$ & $\begin{array}{c}\text { ND } \\
\text { ND } \\
-7 \pm 3 \\
-8 \pm 3 \\
-9 \pm 3 \\
-11 \pm 2\end{array}$ \\
\hline ss- $(\mathrm{dT})_{n}$ tail length $(n)$ & \multicolumn{2}{|c|}{$\Delta C_{\mathrm{p}, \mathrm{obs}}\left(\mathrm{kcal} \mathrm{mol}^{-1} \mathrm{~K}^{-1}\right)$ in $10 \mathrm{mM} \mathrm{MgCl}_{2}$} & \multicolumn{2}{|c|}{$\Delta C_{\mathrm{p}, \mathrm{obs}}\left(\mathrm{kcal} \mathrm{mol}^{-1} \mathrm{~K}^{-1}\right)$ in $0 \mathrm{mM} \mathrm{MgCl}_{2}$} \\
\hline $\begin{array}{l}0 \\
6\end{array}$ & \multicolumn{2}{|r|}{$\begin{array}{l}-1.2 \pm 0.2 \\
-1.6 \pm 0.3\end{array}$} & \multicolumn{2}{|c|}{$\begin{array}{l}-0.5 \pm 0.3 \\
-1.6 \pm 0.4\end{array}$} \\
\hline
\end{tabular}


Table 3

Temperature dependence of the equilibrium constants $\left(K_{\mathrm{BC}}\right)$ for RecBC binding to a blunt-ended DNA. (buffer M plus $100 \mathrm{mM} \mathrm{NaCl}$ and the indicated $\left.\left[\mathrm{MgCl}_{2}\right]\right)$

\begin{tabular}{ccc}
\hline Temperature $\left({ }^{\circ} \mathbf{C}\right)$ & $\boldsymbol{K}_{\mathbf{B C}}\left(\mathbf{1 0}^{\mathbf{7}} \mathbf{M}^{-\mathbf{1}}\right)$ in $\mathbf{1 0} \mathbf{~ m M ~ M g C l}_{\mathbf{2}}$ & $\boldsymbol{K}_{\mathbf{B C}}\left(\mathbf{1 0}^{\mathbf{7}} \mathbf{M}^{\mathbf{- 1}}\right)$ in $\mathbf{0} \mathbf{~ m M ~ M g C l}_{\mathbf{2}}$ \\
\hline 5 & $2.0 \pm 0.7$ & $0.8 \pm 0.1$ \\
15 & $3.7 \pm 0.7$ & $0.8 \pm 0.1$ \\
25 & $1.6 \pm 0.3$ & $0.56 \pm 0.05$ \\
\hline
\end{tabular}


Table 4

Observed enthalpic change ( $\Delta H_{\text {obs }}$ ) for RecBC binding to one end of the DNA VI series molecules. (buffer M plus 10 $\mathrm{mM} \mathrm{MgCl} 2$ and $100 \mathrm{mM} \mathrm{NaCl}$ at $\left.25^{\circ} \mathrm{C}\right)$

\begin{tabular}{ccc}
\hline$(\mathbf{d T})_{\boldsymbol{n}}$ tail length $(\boldsymbol{n})$ & $\boldsymbol{\Delta H}_{\text {obs }}\left(\mathbf{k c a l}^{\mathbf{1}}\right)$ for DNA VI (twin tails) \\
\hline 0 & $-17 \pm 4$ \\
2 & $-34 \pm 3$ \\
4 & $-49 \pm 3$ \\
6 & $-64 \pm 3$ \\
8 & $-63 \pm 3$ \\
20 & $-65 \pm 3$ \\
\hline
\end{tabular}

